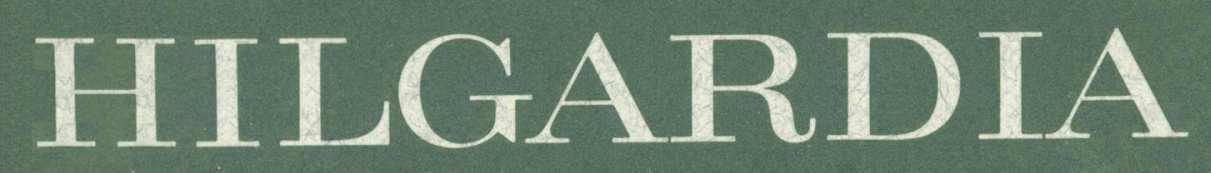

AJOURNAL OF AGRICULTURAL SCIENCE PUBLISHED BY THE CALIFORNIA AGRICULTURAL EXPERIMENT STATION

Volume 40, Number $18 \cdot J u l y, 1971$

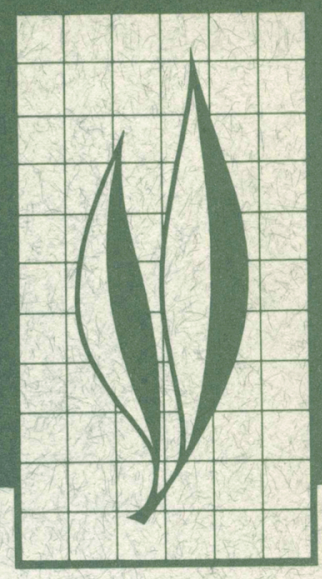

\title{
Fire Blight of Pome Fruits: The Genesis of the Concept that Bacteria can be Pathogenic to Plants
}

Kenneth F. Baker

THIS ENDS VOLUME 40 


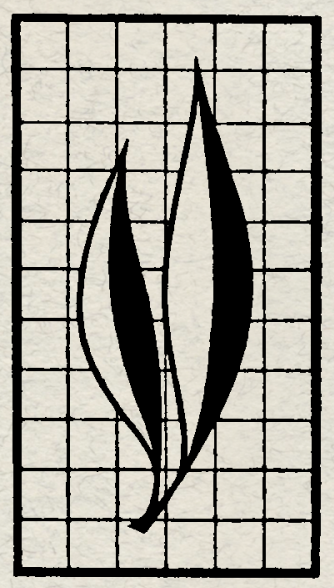

This paper reviews American literature on fire blight disease of pomaceous fruits and presents proof that the concept of certain bacteria as a cause of plant disease was slowly developed by various growers and plant pathologists between 1846 and 1901. Growers first observed fire blight, proved its transmissibility, confirmed its identity on pear and apple, and recognized the importance of flowers as avenues of infection. It then remained for plant pathologists to discover and prove that a specific bacterium, Erwinia amylovora (Burrill) Winslow et al., caused the disease, and that insects could spread the bacterium. Study of the literature shows that if any one person must be given the honor of final proof of the theory it should be J. C. Arthur, and that M. B. Waite was first to show that insects could act as vectors of a plant pathogen, the fire blight bacterium.

THE AUTHOR:

Kenneth F. Baker is Professor of Plant Pathology and Plant Pathologist in the Experiment Station, Berkeley. 
Kenneth F. Baker

\section{Fire Blight of Pome Fruits: the Genesis of the Concept that Bacteria can be Pathogenic to Plants ${ }^{1}$}

\section{INTRODUCTION}

Fire blight of PeAR, apPle, QUiNCE, and other pomaceous fruits has, at several times and places, threatened the survival of the pome-fruit industry. The causal bacterial pathogen, endemic on wild crabapple, hawthorn, serviceberry, or mountain ash in the northeastern United States, was first observed on pear and quince in New York in 1780. It became prevalent and destructive in the eastern states after 1826; it reached Illinois by 1882, and California by 1887 , probably with the numerous shipments of nursery stock made during that period.

Fire blight of pear and apple was discussed in more U. S. publications in the last half of the nineteenth century than any other horticultural problem. In the absence of facts, there were many ideas about the cause of this trouble, and they were ably defended by growers and early investigators who advanced them. Some were reasonable and logical guesses, others were based on remarkably farsighted and pertinent experiments. The better growers made perceptive observations and tests because of their intimate daily contact with the problem and their intense personal interest in it. They clearly defined the fruitful areas for investigation and blazed trails that investigators were to follow. That a bacterium, Erwinia amylovora (Burrill) Winslow et al., was the cause of fire blight remained, however, for plant pathologists to prove. This demonstration is nearly always attributed in textbooks to Thomas Jonathan Burrill, of the University of Illinois, in 1877-83, with little reference to other investigators. Because this discovery also established the concept that bacteria were able to produce disease in plants, it is of importance to examine the facts in this matter.

Despite man's predilection for attributing complex political, economic, or scientific historical events to an individual, they usually are the culmination of the efforts of many men (Hook, 1943). In the field of biology, this predilection frequently creates the impression that the investigator was a brilliant analyst or a lucky prospector, when in fact he may have only taken the obvious next step. Furthermore, this tendency is strengthened today by the wide circulation a fruitful idea may attain prior to publication because of greatly increased unrecorded oral communication at meetings, congresses, and laboratory visits, and it is reinforced by the present emphasis on concise writing and minimal literature review. It is now increasingly difficult to trace the genesis of a concept, and the convenient

\footnotetext{
${ }^{1}$ Submitted for publication December 4, 1970.
} 
idea of its monophyletic origin is often accepted.

The concept considered in this paper is not clouded by such factors. Because of the prompt, voluminous, and even repetitious publications of the time, the sources of most of the ideas can still be traced. Bacteria were involved, a new class of plant pathogens so minute they could be detected only with the recently available compound microscope. Means for pure-culture studies and classifica- tion of these microorganisms were also developed about this same time.

This paper reconstructs from widely scattered sources the steps in clarification of the cause of fire blight and, through it, establishment of the concepts that bacteria are able to produce disease in plants, and that insects may transmit plant pathogens. Elliott (1930, 1951) provides a bibliography of over 400 references on this disease up to 1948.

\section{ORIGIN AND SPREAD OF FIRE BLIGHT}

\section{Early history of pome fruits in America}

The Virginia Company sent a pinnace to Jamestown in 1622 carrying wheat, barley, garden seeds, and fruittree scions. The apples, pears, and other fruits reported by Captain John Smith in 1629 probably came from this stock (Taylor, 1898). The Records of the Governor and Company of the Massachusetts Bay in New England, Memorandum of March 16, 1629, had an entry: "To provide to send for New England:-Peare, aple, quince kernells, pomegranats. ..." (Massachusetts Records, 1853). The pear and apple were thus introduced to the east coast of North America by the English and French. These fruits were introduced to the Pacific Coast through the Jesuit missions in Baja California (16971767) and by the Franciscan missions in California after 1769 .

There are many records of plantings of pear, apple, and quince on the east coast in colonial times. Most of these trees were seedlings, and were grown without fertilizers, pruning, cultivation, or spraying. The fruit was of low quality, and used mainly for preparation of cider and perry. As Hedrick (1917) has commented, “. . . fruit growing in America had its beginning and for two hundred years had almost its whole sustenance in the demand for strong drink. This is shown in almost every page of the horticultural literature of the times and in the laws of the colonies restricting prices and levying taxes on liquors made from fruits."

Budding and grafting of apples and pears was practiced in America by 1647 (Taylor, 1898), but apparently was rare until after 1730. The nursery of Robert Prince at Flushing, Long Island, New York offered named varieties by 1767 (Hedrick, 1921). The pear was extensively grown from 1820 to 1870 , but then declined in popularity, largely because of the severity of fire blight. Culture of apples and pears remained rudimentary until near the end of the nineteenth century. In 1850, for example, it was estimated that it cost only 2.5 cents per barrel to produce apples in New York (Hedrick, 1933). The trees were slow-growing and undoubtedly quite resistant to fire blight.

\section{The first appearance of fire blight}

Erwinia amylovora seems to be endemic in the eastern United States (Arthur, 1886a; van der Zwet, 1968a). It was 93 years after it was first reported in 1780 before it reached the Pacific Coast, and 109 years before it spread from this continent. The bacteria probably occurred in indigenous crabapple, Crataegus, Sorbus, and Amelanchier. The time of their spread to apple 
and pear will probably remain unknown because these hardened trees received scarcely more attention than did the native plants, and pests and diseases were then considered to be a punishment for mankind's sins, or to be due to some environmental condition. Furthermore, fire blight probably was not very damaging to pears and apples grown in this primitive manner, since numerous trees planted before 1650 were still alive 200 years later.

The earliest known record of fire blight of apples, pears, and quinces was by William Denning (1794) in New York, who attributed it to a stem borer: "I first observed it in my orchards in the vicinity of Hudson's river, north of the Highlands, in the year 1780. I. have since observed its baneful progress further south. And, if I am not mistaken, it is spreading rapidly. I have observed it also, attacking pear trees and quince trees, to the total destruction of them in a few years. ... As I observed the young, remote, and tender shoots first affected, I traced the malady to the spot where the sap ceased to flow, but could discover no external cause. ... All the ... trees I found perforated with worm-holes. . . . This disorder appears to me to be of a more serious nature than any thing that has ever infested orchards. . . . farmers . . have . . . generally answered, the trees were blasted by lightning, and this I found to be the prevailing opinion."

John Lowell (1826) also wrote: "I have known such an effect to be produced on the pear for more than forty years. ... let us . . . as rational men proceed to cut off, not the diseased part alone, but all the limb to its junction with the main stem. ... I am convinced by trial, that we shall [then] never be much troubled with it."

William Coxe (1817), in one of the earliest American pomological books, gave a full description of the disease on pears: ". . . fire blight, frequently destroys trees in the fullest apparent vigour and health, in a few hours, turning the leaves suddenly brown, as if they had passed through a hot flame, and causing a morbid matter to exude from the pores of the bark, of a black ferruginous appearance; this happens through the whole course of the warm season-more frequently in weather both hot and moist, affording reason to believe that it arises from the rays of the sun operating on the vapour, or clouds, floating in the atmosphere, either by concentration or reflection."

Coxe reported that succulent shoots had the most severe blight, and that pruning methods which did not stimulate soft growth reduced the severity of the disease. Others also thought that the sun's rays, in conjunction with a misty humid atmosphere, deranged the vital activities of the plant and induced this disease (Ernst, 1848).

\section{Spread of the disease}

Horticultural literature indicates that the disease was prevalent in 1826 and 1832, and widely and destructively epidemic in pears in 1844 (Beecher, 1844), but had subsided by 1846 . The Pennsylvania State Horticultural Society in 1837 offered "a premium of Five Hundred Dollars to be paid to the person who shall discover and make public an effective means of preventing the attack of . . . pear blight." Many panaceas were offered, but no award was made (Fletcher, 1931-33; Hedrick, 1933). The disease continued to be periodically destructive, however, and was spoken of (Baker, 1886) as "the worst malady with which the cultivator of the pear has to contend." It was epidemic in 1875 (Arthur, 1886b), and this situation undoubtedly stimulated research on it. In southern Illinois in 1882 it was reported that "pears have failed, utterly failed, so that none are now cultivated for market. The blight has destroyed the trees--branch and root" (Hallam, 1883).

The disease was first found on the 
Pacific Coast near Chico, in Butte County, California in July, 1887. Identification was confirmed in 1888 from specimens sent to B. T. Galloway, Chief of the Section of Vegetable Pathology, Division of Botany, U. S. Department of Agriculture (Klee, 1889). This identification was confirmed in 1901 by Newton B. Pierce, pathologist of the Pacific Coast Laboratory of the U. S. Department of Agriculture in Santa Ana, California (Gardner and Ark, 1964). The pear had then been grown in California for at least 100 years. George Vancouver, the English navigator, found all the hardy fruits growing at Spanish missions in California when he visited in 1792. As the missions had brought pears and apples from Europe by way of Mexico, this is evidence against the theory of introduction of the disease from Europe (Hedrick, 1921).

The disease was severe in pear orchards of the southern San Joaquin Valley by 1900 and appeared in southern California in 1899. The disease quickly developed at various points on the Pacific Coast after its appearance in California. As many of the nursery trees planted on the Pacific Coast had been grown in the midwest and eastern states, it is probable that there were a number of independent introductions of the pathogen to the area. The disease destroyed 70 per cent of the pear trees in inland Washington in 1900-05; it was general in Idaho by 1904 (Chisholm, 1905), and appeared at Hamilton, Montana in 1905 (Swingle, 1921). The pathogen occurred in the Rogue River Valley of Oregon by 1908 , and soon reached the Umpqua and Hood River Valleys; it appeared in the Willamette Valley in 1915 (van der Zwet, 1968a). The disease was found in British Columbia in 1911 (Eastham, 1924). There was a national epidemic of the disease in 1914-15 (Smith, 1920).

Foreign countries in which the disease now occurs, and the date of first appearance in each are as follows: Canada by 1840 (Harrison and Barlow, 1904); Japan, 1903 (Uyeda, 1903); New Zealand, 1919 (Cockayne, 1920); Mexico, 1921 (Ramirez, 1921; Robles Gutiérrez, 1943) ; China, 1955 (Ciferri, 1955); England, 1958 (Crosse et al., 1958); Chile, 1959 (van der Zwet, 1968a) ; Egypt, 1964 (El-Helaly et al., 1964); South Vietnam, 1965 (My, 1965) ; Poland, 1966 (Borecki et al., 1967) ; Netherlands, 1966 (Maas Geesteranus, 1966, but eradicated in 1967, van der Zwet, 1968a) ; Guatemala, 1968 (Schieber and Sanchez, 1968); Denmark, 1968 (Johansen, 1969; Klarup, 1969). Other reports, unconfirmed or thought to be confused with Pseudomonas syringae, are from Colombia, France, Italy, Rumania, Switzerland, and U. S. S. R. (Commonwealth Mycological Institute, 1969; van der Zwet, 1968a, 1970). Australia has been able to prevent the introduction of the pathogen.

The disease has now assumed such world importance that an international Fireblight Colloquium was held in Paris in September, 1970, by the European and Mediterranean Plant Protection Organization.

Importance of the disease in California. The loss of pear trees in California from 1900 to 1910 was catastrophic. "One-third of this [the pear orchards of California], at least, has already been destroyed. . . ." reported the 1906 Yearbook of the U. S. Department of Agriculture (Wilson, 1907). Figures of the U. S. Census show a 28.1 per cent decline in total pear trees in California from 1900 to 1910 (fig. 1). A comparable decline in bearing trees is obscured by a lack of figures on this category for 1900. In four counties (Fresno, Kern, King, Tulare) of the southern San Joaquin Valley there were 156,429 trees (94.9 per cent) lost between 1901 and 1904. The pear industry has never reestablished there (Anonymous, 1902, 1905). U. S. Census figures 
show a loss of 703,892 (28.1 per cent) pear trees in California in the 10 years following 1900 . The important pear center in 13 counties (Sacramento, Solano, Sonoma, Napa, Yolo, El Dorado, Placer, Sutter, Colusa, Lake, Butte, Yuba, and Nevada) north of Sacramento, however, sustained slight loss of trees between 1901 and 1904; bearing trees increased by 63,471 (9.8 per cent) in the area. Three of the counties (Nevada, Sutter, and Lake) lost 23,287 trees (34.4 per cent), but Butte County, where the disease first appeared, apparently had no losses. In five southern counties (Los Angeles, Riverside, Ventura, San Bernardino, and Orange) 15,499 trees (33.3 per cent) were lost in this period (Anonymous, 1902, 1905).

The Reports of the County Horticultural Commissioners during the fire-blight epidemic in southern San Joaquin Valley convey little of the anxiety which must have been felt by the growers. There were 88,535 bearing and 45,325 non-bearing pear trees in Fresno County in 1899. "The deciduous fruit orchards of the county are generally in good condition, and the present season has been one of exceptional profits. ..." Fire blight was not mentioned in 1900 (Grainger et al., 1901). There were 125,040 pear and 25,060 apple trees of all sizes in 1901. "We had a large crop of all kinds of dried fruits with the exception of pears, which were very badly blighted. Our green fruit shipments were light, owing to our small crop of pears. . .." (Weaver, 1902). Although there were only 1,520 pear and 10,600 apple trees of all sizes reported in 1904, fire blight was not mentioned. "The orchards of the county are .. . reasonably free from insects and diseases" (Chauncey, 1905). In 1906 there was a brief epitaph: "Pear culture in this county has become a thing of the past, owing to the ravages of the pear blight, and we advocate the destruction of every blighted or liable to be blighted tree, and a stoppage of planting for two years, when we feel confident Fresno County can begin a new and successful industry in pear growing" (Schell, 1907).

The disease was not mentioned in the Reports of 1899 or 1900 in Tulare County, but in 1901 "The pear crop was almost a complete failure caused by the pear blight. It is the opinion of this Board that many pear trees affected with the blight will recover. Thousands of pear trees have been cleaned of the blight as fast as it appeared" (Fowler, et al., 1902). There were in that year 24,069 pear trees in the county. Although there were only 5,895 pear trees remaining in 1904, fire blight was not even mentioned (nor was it in 1906), and "The Commissioners . . . are especially proud of the cleanliness of our orchards and vineyards. . . ." (Riley, 1905). Seldom has such a thriving industry been so rapidly destroyed with so little official notice taken of it.

There is a suggestion that the overall situation may not have been as economically disastrous as one might suppose. "Pear blight cut very largely into this fruit during the season of 1905 , and ... the pear crop ... may be said to have been a failure, the total output being less than that of any year since 1895 and less than one half the crop of the preceding year. ... Prices were phenomenally high, but even at the prices offered, the fruit could not be obtained. ... it is probable that, despite the short crop, more money was received for pears during the season of 1905 than in any previous year" (Anonymous, 1907). This viewpoint must have provided scant comfort to the grower who had removed his orchard because of blight.

The reason for the smaller losses in the Sacramento than in the southern San Joaquin Valley was partly climatic (the Sacramento Valley is cooler), but there is a suggestion that even in the former a vigorous cleanup campaign was necessary. "Many of the growers 


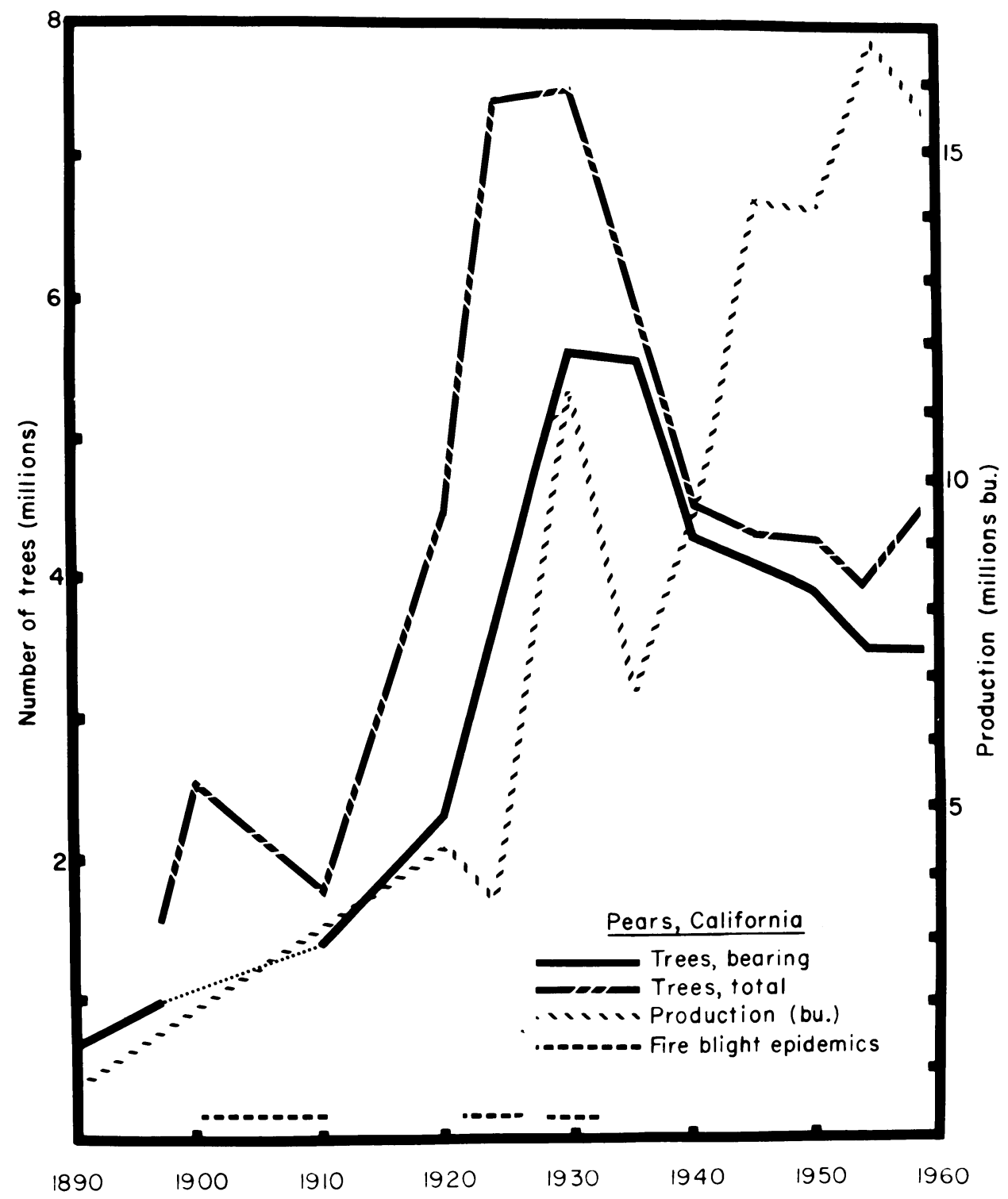

Fig. 1. Number of bearing and total pear trees in California, 1890 to 1959, and fruit production during that period. Years of severe fire blight are indicated. Dotted area in graph for bearing trees indicates lack of data for 1900. For further details see pages 606-10. Figures shown are based on U. S. Census of Agriculture reports.

club together and hire an expert to keep their orchards free from blight. But with all the careful attention that has been given this work, there.... was a loss of about 3.8 per cent of the pear trees from butt blight last season" (Cutter, 1907). Fire blight has remained a continuing threat to the California pear industry, which is now lo- cated almost entirely in the northern half of the state. For example, D. G. Milbrath reported (Anonymous, 1924) that in California in 1923, "There are few orchards in the diseased areas which did not have some blight. In some orchards all trees were severely infected. The loss in the state was about $\$ 2,000,000$ based on removed trees, se- 
verely pruned trees and crop reduction. In Sacramento County out of $1,000,000$ trees 30,000 were removed." The effect of this epidemic was reflected in production (fig. 1).

The heavy plantings in the Sacramento area up to 1930 replaced trees lost from fire blight. The small decline of production in 1920-24 resulted from a fire-blight epidemic there, as did the severe decline in 1930-35. Between April 1930 and April 1931 there were 200,983 pear, 3,297 apple, and 55 quince trees removed in Sacramento County. "Pear blight was ... directly responsible for at least 75 per cent of the total and indirectly responsible for a large portion of the balance. ... the cost of fighting pear blight has been as high as one hundred twenty-five dollars per

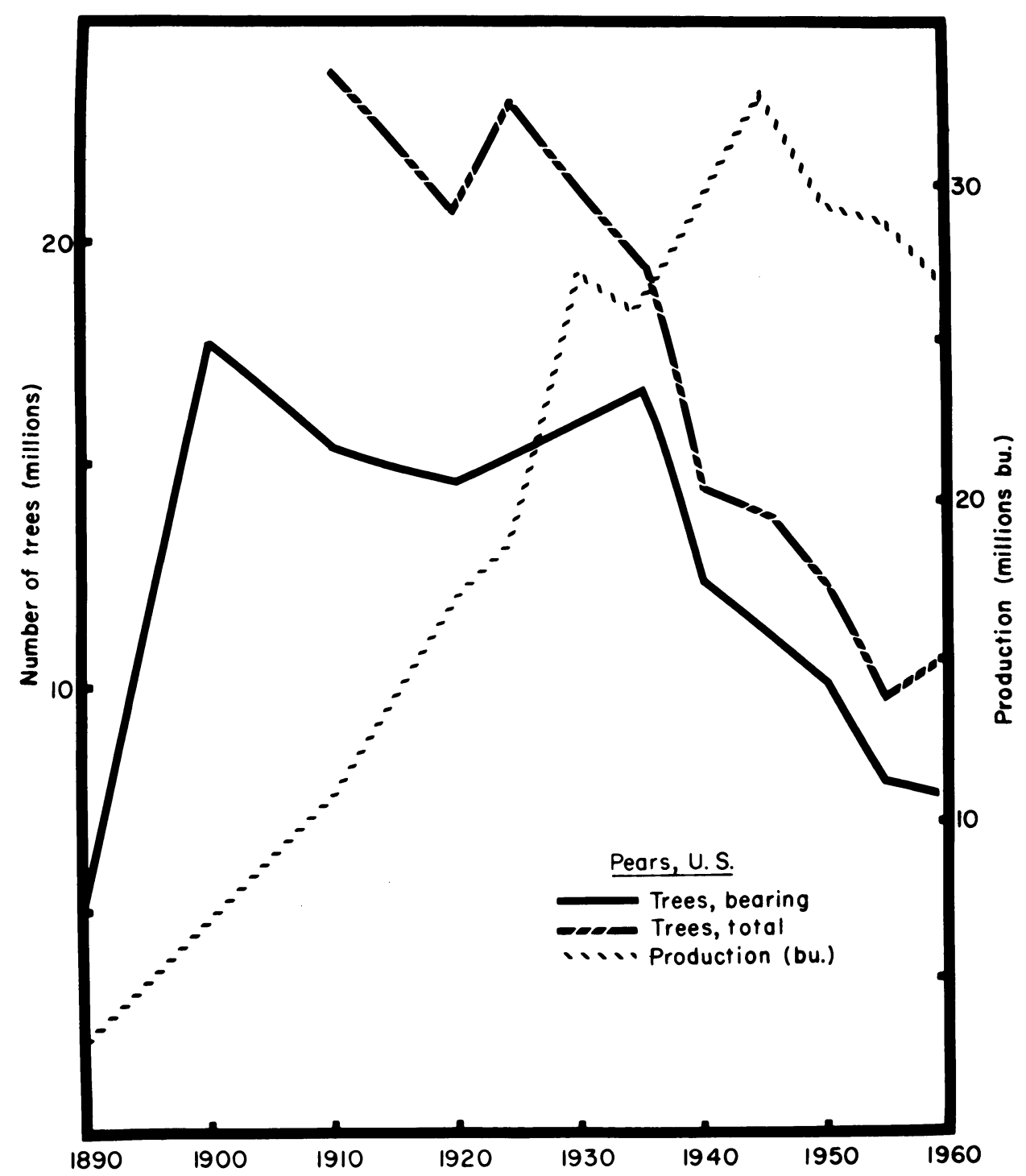

Fig. 2. Number of bearing and total pear trees in the United States, 1890 to 1959, and fruit production during that period. For further details see page 610. Figures shown are based on U. S. Census of Agriculture reports. 
acre with an estimated average figure of sixty dollars" (Morrison, 1931). That there were 17,450 pear trees planted during this period illustrates the continuing nature of the battle. There was a large decrease (39.6 per cent) in production between 1930 and 1935; this is, however, an exaggerated figure because of the unusually high production of 1930 . There was also a 10.9 per cent decrease in total number of pear trees during this period (fig. 1). Fire blight was certainly involved in these trends.

Despite the steady decline in the number of pear trees in the U. S. and in California since 1930, fruit production has tended to increase (fig. 1). Thus, the production per bearing tree in the U. S. rose from 0.60 bushels in 1890 to 0.73 in 1910 , to 1.69 in 1930 , to 2.90 in 1950 , and to 3.69 in 1959 . Comparable figures for California were 0.83 bushels in 1890, 1.92 in 1920, 2.02 in $1930,3.64$ in 1950, and 4.58 in 1959 . Plantings were heavy in the U. S. in 1890-1910, more than replacing trees lost from fire blight. The declining number of bearing trees from 1900 to 1920 probably reflects losses from fire blight, particularly in California. There was a slow increase in the number of bearing trees until 1935, followed by a steady decline to the present. Production increased steadily up to 1945 because of greatly increasing yield per tree and increasing planting in areas less subject to fire blight (fig. 2).

There was heavy planting of pear trees up to 1924 , then a decline to the present. Production rose steadily until 1945, with a slight drop in 1930-35 (fig. 2); this probably was a result of the California fire-blight epidemic as California was then producing 41.9 per cent of the nation's pears. This increasing production during a period of progressively fewer trees must have reflected improved culture, including disease control.

Careful eradication of carryover cankers, and spraying with antibiotics to reduce flower infection, have provided fair control of the disease in the important growing areas centering on Sacramento. However, the disease still causes frequent severe losses there, particularly in Placer County. Attractive highly marketable varieties, such as the Forelle, cannot be grown successfully because of extreme susceptibility to the disease.

Control measures against fire blight in the United States have recently been summarized by van der Zwet (1968b).

\section{STUDIES PRIOR TO 1876 ON THE CAUSE OF FIRE BLIGHT}

\section{Theories of the cause}

It is not surprising that there were many conjectures as to the cause of the disease. The insect theory of 1794-1847 (Barry, 1847; Buell, 1827, 1828; Denning, 1794; Lowell, 1826) contended that Xyleborus beetles, borers, or other insects girdled or killed the branches. Lightning (Anonymous, 1829; Denning, 1794; Eaton, 1847; Tice, 1879) and electricity were frequently suggested as the cause of blight from 1794 to 1879. Professor J. H. Tice commented: "I have observed that blight makes its appearance suddenly . . . a very few days after violent thunder storms. I hence have an hypothesis that electrical explosions . . . may possibly stand to it in the relation of cause. ... Good housewives know that thunder sours the milk . . . when the trees are in bloom ... the nectar of the pistil is decomposed ... by the discharge from its summit . . ; it therefore sours, and fructification cannot take place. . . . [In] the apple and pear blight ... it is well known that fermentation takes place in the sap; it has turned sour, and scalds the tree as it descends."

The frozen-sap theory (Beecher, 
1844; Downing, 1845) of 1844-45 supposed that autumn or winter freezing of unripened wood produced a poison carried in the sap in the spring and summer, which caused the death of parts. The fungus theory (Cooke, 1867; Hull, 1869; Meehan, 1868a; Meehan and Hunt, 1875; Salisbury and Salisbury, 1864; Taylor, 1877) of 1863-75 was proposed following microscopic examination of tissues, but apparently the fungi were neither cultured from nor inoculated into the host. Although J. H. Salisbury and C. B. Salisbury (1864) attributed the disease to a powdery mildew, Sphaerotheca pyri, most advocates (e. g., Meehan and Hunt, 1875) of this theory were discreetly unspecific.

These theories were commonly debated in horticultural journals, often with considerable insight (Gookins, 1846; James, 1849). J. H. James (1849), for example, wrote concerning the frozen-sap hypothesis: "If the sap is poisoned and carried inwards it would also ascend through the alburnum [sapwood], and infect the top. But this is not the case: grafts taken from a blighted top, will grow into healthy branches. . . . The injury may be regarded as entirely local."

Attempts were even made in 1863 and 1869 to find the correct explanation by ballot of the Illinois State Horticultural Society. "Here the discussion ended. An effort to commit the majority of the Society in some manner, by a resolution indorsing the insect theory, failed-the resolution was tabled" (Anonymous, 1863). "I move that the Society recommend that members rootprune their pear trees by the method and at the time recommended in my report, and report from time to time to the Society. Carried" (Hull, 1869).

J. A. Kennicott (1851), in Illinois, commented that his quince trees, which "were loaded with flowers this season" were severely attacked. "I noticed that the sets were withering, and in a few days I found the extremities of nearly all the shoots blighted. . . . I found the popular opinion of the cause of this affection to be . . insects. In accordance with this notion, I have looked for insects, and you may have heard, perhaps, that Doctors are famous for finding what they look for in post mortem examinations. With the aid of a tolerable magnifier, as well as my desire to find them, I discovered a few grubs ... a and some lively little insects ... , and yet I have ... come to the conclusion that these are effects of decomposition, rather than causes of disease.... I think that it is a true epidemic, which attacks . . . the grossest feeders and enfeebled constitutions. . . . I think that ... the choice varieties receiving higher culture are becoming more and more enfeebled in constitution."

\section{Early transmission tests}

It was frequently inferred that fire blight, like cholera and anthrax, was infectious and perhaps of similar cause. Reuben Ragan was reported (Gookins, 1846) to have made inoculation tests in this connection in 1845 ; this is probably the first recorded transmission test with this pathogen: “. . . a few days previous, he had, by way of experiment, inoculated a thrifty young pear tree in his nursery with the sap of a blighted tree. ... He had made an incision about three feet from the ground, lifted the bark as in the process of budding, and injected a small quantity of the diseased sap. We found the leaves of the patient changing color, and emitting that peculiar odor which . . . is always present in cases of blight, and upon applying the knife, the inner bark was found to be black from the root to the top, while nothing of the kind appeared elsewhere in the nursery. . . . The atmosphere is, I believe, generally admitted to be the medium by which they [epidemics] prevail, and are carried from place to place. What that subtle principle may be, ... by which infection is retained and transmitted ... human science has not discovered, ... but that 
such a principle exists, is sufficiently obvious from its effects."

Several other investigators also reported that the infectious entity could be transmitted to healthy trees by the pruning knife. Herman Wendell (1850) of New York said in 1849: "Thinking that I had discovered blight to be either contagious or epidemic (which I shall not as yet say,) from the fact, that when a tree was attacked, others in its immediate vicinity were apt to be affected in a similar manner. ... the moment a tree is discovered to be attacked, that moment I amputate the limb far below the least appearance of disease. I am also careful that the blade of the knife is perfectly clean, and that it has none of the sap of a diseased tree adhering to it; because I have known many valuable trees destroyed by having been inoculated in this matter with the vitiated sap of a diseased tree."

E. S. Hull, the Illinois State Horticulturist, successfully transmitted the infective agent by tissue transfer at least by 1870 . In 1868 he reported (Meehan, 1868b) "I . . . am convinced that fungus is the principle or sole cause of pear-blight. I have inoculated trees with it when the sap was in active circulation, and it has spread badly; when the sap is at rest, it did not spread so much." In 1870 he stated (Hull, 1870): "In my report . . . for 1868, I detailed my experiments in inoculating healthy pear and apple trees with blight. To that report I will now add that pear, apple and quince tree blight appear to be identical, since the little cellular growth when taken from one of these trees and introduced into the circulation of either of the others, it will induce the disease, to all appearance, the same as when it occurs in the usual way."

In 1871 Hull reported: "We cut from it [a blighted apple twig] . . . several small slices of bark, going deep enough to include a thin slice of wood; with these we inoculated several succulent pear shoots, by tying in the pieces of bark as in budding. . . . after a lapse of thirty-four days . . . we found them all blighted. The blight had gone above inoculated parts, varying from one halfinch to two inches, and descended from three to fourteen inches, further confirming the opinion we have before several times expressed, that the fungi causing pear and apple tree blight are identical. . . there are many causes which retard blight, such as noncultivation, drought, seeding the ground under the trees to grass, overcropping, root-pruning, etc. In short, anything inducing early maturity, or tending to arrest the rapid flow of sap, will prevent this disease from being disseminated through the tree." (Hull, 1871).

Professor J. B. Turner (1879), who had taught Burrill at the Illinois State Normal School prior to 1865 , stated "I found that this disease is exceedingly contagious; for if I used my knife to prune a healthy tree after having used it in shaving the diseased one I communicated the disease to that tree."

\section{Early investigations of bacteria in relation to other plant diseases}

There were other investigations which strengthened the idea that pathogens could cause disease of this type. F. M. Dränert reported studies on a disease of sugar cane in Bahia, Brazil, now accepted as caused by the bacterium, Xanthomonas vasculorum (Dränert, 1869; Smith, 1914). He wrote: "In the fully developed disease a yellow, thick, fluid substance flows out of the bundles. This substance hardens in the air, but dissolves in water, and under the microscope, with very high magnifications, is seen to have only a granular structure. When dissolved in water one can make out very minute cells lying in amorphous heaps, or attached to each other in necklace fashion. . . . From such cane the yellow material was collected, which, dissolved in water, appears as a micrococcus."

Erwin F. Smith (1914) accepted 
Dränert's work, and provided an explanation of some of his incorrect conclusions: "Dränert was probably the first person to describe this disease in a scientific publication, and certainly the first one to find bacteria in connection with it. ... as a result of microscopic examinations, he found various minute vegetable organisms in the languishing cane, and to them he ascribed the disease. Accepting Hallier's peculiar view of polymorphism, he believed all these to be various stages of one organism, and experimenting in the same crude way as Hallier, believed he had demonstrated that one grew out of the other. He speaks mostly of an alga as the cause of the disease, but this is only because he believed that to be the terminal stage in the development of the microscopic organisms (bacteria) seen by him in the yellow gum. These latter were considered to be the spores of the algae, or the reduced forms of the spores. . . O Owing to the imperfect technic of the time he was unable to obtain from his cultures results of any value. ... his micrococcus is about the right size and it is very easy to understand how he should have mistaken short rods for a coccus, especially with the crude microscope he is likely to have used. There is no doubt whatever in my own mind that the Brazilian cane-disease studied by him was really that subsequently described from Australia by Cobb."

Dränert made no cultures or inoculations, but the observational evidence was accepted by Smith, a critical person and the leading phytobacteriologist of the time, as indicating that Dränert saw bacteria in the diseased cane tissue. The evidence does not, however, justify claims (Bitancourt, 1943; Puttemans, 1940) that "This ... represents the first report in the world of a bacterial disease of plants...", even though it was as good as that in the first papers by Burrill (1877, 1878).

Woronin (1866) had microscopically demonstrated the presence of bacteria in root nodules of lupin in 1866 , a fact confirmed by Beijerinck (1888). Davaine (1868) had also shown, albeit crudely, that an infusion containing Bacterium putredinis produced a softrot in plant tissue.

The first proof that a specific microorganism could cause a specific disease of an animal was provided by $R$. Koch (1876) on anthrax in 1876.

\section{7-1885: PIVOTAL YEARS IN DETERMINING THE CAUSE OF FIRE BLIGHT}

When Thomas J. Burrill began his studies on fire blight about 1876, a number of points about the disease had been demonstrated about as well as the available techniques permitted. Transmission of the infective agent of fire blight by sap or by tissue from diseased twigs had been demonstrated and reported by at least three different workers in 1845-78 (Hull, 1871; Ragan, in Gookins, 1846; Wendell, 1850). It had been shown that the agent causing apple blight would produce the disease on pear (Hull, 1871), and the diseases were thought to be identical (Denning, 1794; Hull, 1870, 1871). It had long been noted that factors which increased succulence of host tissue increased susceptibility to fire blight (Coxe, 1817; Denning, 1794; Downing, 1845; Hull, 1871; Kennicott, 1851; Meehan, 1868a). Several theories as to the cause were still discussed, but a fungus was widely considered to be the most probable agent. Although bacteria were fairly well-defined entities by this time, it should be noted that they were not yet clearly separated from fungi or algae by many biologists (e.g., Burrill, $1882 a)$. It is now generally accepted that bacteria, whether recognized as such or not, had several times been ob- 
served in plant tissue which was either destroyed or stimulated to gall formation. The idea that bacteria could produce disease in plants was, therefore, not as original as Burrill supposed in 1879. As suitable pure-culture methods had not yet been developed by 0 . Brefeld (1875-83) and R. Koch (1881), much of this early work is today not very convincing.

\section{The gradual development of Burrill's concept}

In Burrill's first paper (1877), reporting his observations on fire blight, he stated "The sap of the newly blighted limbs, especially in the young cells between the wood and bark, swarms with minute living particles, visible only with high powers of the microscope, resembling the spermatia (supposed male elements) of funchi [sic] and lichens.... This [exudate] is almost wholly made up of these oscillating corpuscles...."

Burrill (1878) stated in his second paper: "It has been quite generally conceded ... that this malady is due to the injurious effect of a parasitic fungus....those who have carefully investigated with the microscope, the conditions and progress of the disease, agree in finding evidence of the connection of fungi with the blight of the tree; but no one has yet positively traced what this connection is .... The cambium of the blighted branch, when the trouble first shows itself, and for some days thereafter, is filled with very minute moving particles, very similar to those known as Spermatia in fungi and other low plants.... There is evidence that the theory of the fungus origin of the fire-blight of the pear, and the common twig-blight of the apple, is well founded; ... proof has not yet been obtained as to their causing the death of the limbs, nor as to the real action of any fungi upon the limbs."

Burrill described small "conceptacles" in the bark from which these sper- matia arose, and also reported a Valsa, a Diplodia, and black mycelium on affected plants. He recommended for control, alkaline washes of the trees in winter and the removal of infected limbs. Burrill (1878) in 1877 obviously considered this to be a fungus disease. $\mathrm{He}$ later (1881a) explained this error: "My own mistake ... by which these minute bodies were equivocally referred to the spermatia of some fungus, shows the want at the time of a proper glass .... Only the objectives of sharpest and finest definition give satisfactory results."

The following year he transmitted the disease, and somewhat uncertainly attributed it to bacteria. In a discussion before the Illinois State Horticultural Society in 1878, Burrill (1879) said: "The so-called fire blight of the pear and the common twig-blight of the apple are almost surely... due to the same cause.... If we remove the bark of a newly-affected limb, and place a little of the mucilaginous fluid from the browned tissues under our microscope, the field is seen to be alive with moving atoms known in a general way as bacteria. Sometimes a thick, brownish fluid oozes from the bark of dying limbs. ... This is apparently made up of the living things, myriads of them to be seen at once. A particle of this viscous fluid introduced upon the point of a knife into the bark of a healthy tree is in many cases followed by blight of the part, but with me not in every instance ...the disease spreads more or less rapidly from the point of origin, and upon examination the moving microscopic things are discovered in advance of the discolored portions of the tissues, but not very far ahead-an inch, perhaps. Does it not seem plausible that they cause the subsequently apparent change? It does to me, but this is the extent of my own faith; we should not say the conclusion is reached and the cause of the difficulty definitely ascertained. So far as I know the idea is an 
entirely new one-that bacteria cause disease in plants.... The so-called germ-theory of disease in animals ... is rapidly gaining support and credence. It is not impossible that we are now making a beginning of the application of the theory to the diseases of plants..."

In 1880 Burrill demonstrated that fire blight of pear, twig blight, and trunk sunscald (Burrill, 1885) of apple, and blight of quince were variants of the same malady. He also overenthusiastically suggested that peach yellows, the dying of Lombardy poplar, sunscald of butternut trees, and twig blight of aspen might be due to similar organisms (Burrill, 1881a, b, c, 1882b). He stated (1881a) that "The direct cause of the ... malady is a minute organism belonging to the lowest order of the Fungi, (or, as some say, Algae) best known as Bacteria." He also wrote: "The inoculations of July 1st and 10th were made by cutting pieces of diseased bark freshly taken from the tree, and inserting them after the manner of budding .... These pieces of bark were about three-sixteenths of an inch by two-thirds of an inch. Those made after the date mentioned were performed with a sharp-pointed knife, or needle dipped in the exuding virus ${ }^{2}$ of diseased trees. This was usually collected in the morning and placed in a vial with a little distilled water. Requisite care was always taken to cleanse the instrument thoroughly or to choose a new one when changing the infecting material. Usually, shoots of the current year's growth were chosen for inoculation and the operation performed near the middle, longitudinally. . . . Twenty-one experiments were made by simply applying the virus by means of a brush to the uninjured epidermis of growing shoots or leaves. It is usually supposed that the destruction of affected parts of trees is very sudden. . . . I find the march of the destroyer very irregular . . . , but always slow" (Burrill, 1881b).

Wound inoculations by Burrill on 3-year-old Bartlett and Clapp's Favorite pear trees were 63 per cent successful, while less than 2 per cent of the adjacent trees became infected. Wound inoculations of pear trees with material from pear were 54 per cent, and those with apple material 72 per cent successful. "I think the result may be taken as showing the identity of the disease in the two trees" (Burrill, 1881b) - a conclusion which had been reported by Hull in the same journal 10 years before. Wound inoculations of Angers quince with pear material were 100 per cent successful, and those on 8-year-old Grimes' Golden Pippin apple trees were 30 per cent successful. A total of 69 wound inoculations were made. Trees wounded but not inoculated remained uninfected, as did 54 uninoculated checks. All external applications of inoculum were unsuccessful, including placing infected limbs in healthy trees during rainy weather.

The bacteria were examined with a 1000 -power microscope and found to be about $1 \times 1.5 \mu$ and motile; they were crudely illustrated. Infected tissues were free of starch (this observation was unfortunately made the basis of the name amylovorus later applied to this bacterium), but the cell walls were uninjured (Burrill, 1881a, c). "There is absolutely no trace of other fungous growth in the tissues... until after death has taken place. . . ." (Burrill, $1881 b)$. He observed infected leaves on healthy twigs, and noted that exudate dried on them in a varnish-like layer which contained living bacteria.

Burrill (1881b) realized the tenuousness of his claim by stating "the work was not so extensively prosecuted as I heartily wished it had been. . . . However, the results are sufficiently clear to... establish the aggressive activity of the organisms." Burrill (1882a) felt

\footnotetext{
2 "Virus" was then commonly used to indicate a poison or disease agent, rather than a virus in the modern sense.
} 
that "It is ... now impossible to deny that a specific bacterium is always present in immense numbers in every blighting tree under whatever conditions this takes place. . . I I should not hesitate to make a public trial upon any kind or condition of living pear tree during July and August of any year, anywhere, and predict that at least one-half of the inoculations would plainly show blight within from eight to twenty days."

By 1882 Burrill had become sufficiently convinced that his 1879 hypothesis was correct to name the causal bacterium Micrococcus amylovorus. $\mathrm{He}$ provided a very brief but adequate description (1882c, 1883) and added: "The cause of 'blight' in plants, especially of the pear tree (fire blight) and of the apple tree (twig blight and sun scald). The organism gains entrance to the living tissues through wounds or punctures. . . . The disease is transmissible by artificial inoculation."

By 1883 Burrill (1884) was confident that his bacterium caused the disease: "There seems to have been no attempt to disprove the conclusions as published in our Transactions for 1880 , nor has there been any evidence... that anything besides bacteria does this deadly work in the tissues of our pear trees. ... That a certain and now well-known species of the minute organisms popularly known as bacteria is the real, active and immediate cause of this blight, is a fixed and positive fact-not a fancy nor a theory; a demonstrated and demonstrable truth-not a conjecture.... Beyond this confident assertion of the fact I do not now care to go ..."

Burrill (1884) also exhibited photographs showing the efficacy of careful early removal of cankers in pear trees, along with disinfection of tools and painting of wounds, as a means of disease control. He advocated frequent careful examination of trees in order to remove cankers before they progressed into large limbs.

\section{Burrill's other studies on some supposed bacterial diseases}

The acceptance of the idea of bacterial causation of fire blight of pears on limited evidence perhaps led Burrill into other less fortunate predictions. In 1881-82 he (1881a, $b, c, 1882 c)$ thought that peach yellows, and diseases of Lombardy poplar, butternut, and aspen might be due to similar organisms. Two years later (1884) he seemed less certain about peach yellows, stating ". . . it is impossible for me to have an opinion as to whether bacteria have, or do not have, anything to do with the disease called yellows, but that it does seem probable that there is really more than one disease to which this name is commonly applied."

Burrill (1882d) also suggested that the "poison" of poison ivy was due to a bacterium which he also saw in vesicles produced by juice of the plant on humans. "All the characteristics of these minute things gave conclusive evidence that they belonged to the group of organisms we call bacteria." The next year he (1883) described Micrococcus toxicatus and stated: "In species of Rhus, and believed to be the peculiar 'poison' for which these plants are noted. They may be found in the internal tissues of the stem as well as upon the leaves. Transferred to the human skin they multiply rapidly in number and penetrating the epidermis, through the sweat ducts (?) set up the inflammation so well known. If again transferred to healthy skin the same phenomenon follows."

After his retirement in 1912 Burrill continued his unsuccessful attempts to train nodule bacteria of legumes to establish symbiotic relations with tomato, morning glory, and strawberry (Burrill and Hansen, 1917).

\section{Observations on blossom infection}

That blight bacteria might infect through blossoms was observed at an 
early date. A. Bryant had commented (Meehan, 1868a) that "... pears do not blight... when young so readily as when four or five years old-just as they begin to show signs of fruiting."

George P. Peffer, a Wisconsin grower, commented in the discussion of Burrill's 1882 paper (Burrill, 1882a): "I have experimented upon and also observed closely the blight this year. I had no blight whatever, except upon trees that bloomed, and upon those the blight seemed to commence in the petals of the blossom, and from these continued down into the branch and leaves, killing the branch in every instance if not interfered with. I picked off the flowers in many cases where I observed them affected, and the blight in such cases continued no further. Can you account for it? Answer-No I can only speculate."

Two years later Burrill (1884) reported that: "I am able to confirm the observation of Mr. Pieffer [sic] ... that blight may be introduced through the flowers, and probably without wounds of any kind." Peffer (1882) reported further: "... while the first flowers ... were perfect in form yet failed to set, ...the petals seemed to be burned or scalded soon after they fully opened. ... in a short time not only the petals but the leaves around the flower stems showed signs of blight, and the black liquid usually seen with fire blight ran down from these twigs and affected the last year's wood growth also. Ninetenths of the twigs thus affected perished, a few escaped, where the blossom stem was broken off at the start. . . . All the trees that were in full bloom during those hot days were thus blighted,... while the same varieties standing only a few rods apart that had no blossom stems or were not yet in bloom, escaped altogether. ... the rotten sap or poisonous fluid runs down the petal to the calyx, along the stem of the little apple to the base, ... and then all are affected. ... if the weather is favorable, it works down the new wood growth of the shoot. If the part affected is here removed, or dry weather comes on, the progress is usually checked in most apples, ... but with the pear it is apt to run down the older wood and to extend until the tree is killed, unless the limb or part affected is cut off some distance below where it is discovered... being careful not to use a knife that has been used in cutting the poisoned, blighted wood."

Peffer sent specimens to Burrill, who replied (Peffer, 1882): "There is no question in my mind but that your idea that the blight starts in the blossoms ... is true. It is quite new to me, but I now find similar evidences of the fact here. This disease may start elsewhere, but I think it is pretty well proved that it does not do so without some puncture of the bark or epidermis." Peffer (1881), however, rejected Burrill's idea of the bacterial cause of fire blight, because infection of twigs only occurred through wounds. The bacteria were thought to act on the injured tissue and produce a poisonous fluid which killed tissues over which it flowed. "Some claim that blight is contagious. Rust, mildew and fungoid growth may be, ... but blight cannot be. It is generated in every ... cell ... of the ... part affected, ... and thus gives the conditions necessary to the development of fungoid growth or rust." His question, "What would be the effect of this deadly infection aside from the bacteria on the tender tissues of the bark?" was not answered until the later work of Arthur (1885a, 1886c).

\section{Contemporary (1870-1900) investigators of bacterial diseases of plants}

A number of other plant pathologists were studying bacterial diseases of plants about this same period. Prillieux (1879) studied the rose-red disease of wheat, finding abundant bacteria in 
cavities in the seeds. He made no pure cultures or inoculations, and no one has since confirmed his work (Smith, 1911). Comes $(1882,1884)$ recognized bacteria in several plant diseases in 1880 , but did not use pure cultures, made no inoculations, and the organisms he observed cannot be identified from his descriptions (Smith, 1911). Wakker (1884, 1884-87) published a series of papers on hyacinth yellows. Most of the inoculations were made directly from diseased plants, or "with great care" into sterile nutrient solutions or on gelatin. His first successful inoculations with pure cultures were made in March 1886. Smith $(1896 b, 1911)$ said of these studies, "... none of the early work was better done," and "this piece of work ... is remarkably good, and ... the internal evidence indicates a careful, conscientious, brilliant investigator." Savastano (1887) studied the olive-knot disease, and showed the constant association of the bacteria, grew them in culture media, and successfully reinoculated (Smith, 1911). All of these papers were later than Burrill's studies, and only those of Wakker and Savastano were better work; the studies of Prillieux and Comes were inferior to those of Burrill.

\section{The conclusive studies of}

\section{J. C. Arthur}

J. C. Arthur (1885b, 1886a), botanist at the New York Agricultural Experiment Station in Geneva, began investigations of pear blight in July, 1884, which confirmed and extended Burrill's conclusions. He stated "... at the outstart that the bacterial theory is not absolutely proven, but it has reached that stage of plausibility where it is able to account for the known facts...." Arthur made 14 inoculations by transferring exudate from an infected to a healthy pear stem with a pin, or by puncturing with a pin and applying a drop of water in which slices of an infected apple or pear branch had been rinsed. Eleven of these were successful, but only one out of five was successful on leaves. Nine fruit inoculations from pear, apple, and quince were all successful. Of 14 similar inoculations on apple stems from infected pear and quince, 13 were successful. Of two leaf infections one was successful, and five on apple fruits were successful. Seven similar inoculations on quince stems from infected pear, and six on quince fruits, were successful. Of nine similar inoculations on Crataegus stems, seven were successful, and two out of eight on Amelanchier stems were successful. Seven inoculations on Sorbus, and one each on raspberry, grape, and peach were unsuccessful. Transmissibility and cross inoculations between pear, apple, quince, Crataegus, and Amelanchier were thus confirmed. The most successful inoculations were on succulent young stem or fruit tissues. Green fruits were much more susceptible than ripe ones.

Copiously watering a potted pear tree with bacteria-infested water did not produce infection, Arthur stated. Immersion of a young leaf in such a suspension, or dripping it onto a leaf, was infrequently successful. $\mathrm{He}$ also placed a potted young pear tree and some exuding blighted branches in a bell jar and passed air through it for several hours without transmitting the disease. He thought that dried bacteria were air-borne and could infect the young buds when rewetted; insect inoculation through feeding punctures was also suggested as an infrequent possibility. Microscopic examination ( 400 $x$ ) of the milky exudate from infected stems always showed the presence of bacteria, even when taken from tissue in advance of the discolored area.

Arthur (1885b) recognized one of the defects of Burrill's methods: "It has been shown that the disease is infectious and always accompanied by a specific bacterium, but it has not been 
shown that the bacteria when completely isolated from the fluids about them will convey the disease, or that ... the fluids freed from the bacteria will not convey the disease."

Professor A. N. Prentiss of Cornell University suggested a means of resolving this point. The bacteria were grown for four months in six successive transfers on sterile cornmeal infusions to free them by dilution from juices from the infected host. Inoculation from the sixth transfer into green pear fruits rotted them, indicating that the bacteria were the cause of the disease. An infusion from a blighted pear was filtered through a porous unglazed porcelain vessel, and when the filtrate was inoculated into a green pear fruit no infection resulted. The unfiltered infusion, however, caused rapid decay of similarly inoculated fruits (Arthur, $1885 a, 1886 c)$. "The evidence is thoroughly satisfactory and conclusive. The bacteria accompanying the disease of trees known as pear blight when fully isolated will produce the disease, while the juices in which they live will not. They are therefore the direct cause of the disease" (Arthur, 1885a). This work involved two relatively new techniques, growth of the bacteria on an artificial medium, and use of filtration to eliminate the bacteria. Since unburned clay filters had been used by Tiegel in 1871 and by Eberth in 1872, and the Chamberland filters had been developed in 1884 (Bulloch, 1938), methods of filtration to obtain bacteriafree fluids were available. Smith $(1899 b)$ stated that Arthur "... made pure cultures or what he supposed to be such, and which probably were such, by inoculating tubes of sterile corn meal broth with bacteria from the interior of freshly blighted tissues."

Arthur (1885c, $d, 1886 c)$ confirmed the observation of Bryant (Meehan, 1868a), Peffer (Burrill, 1882a; Peffer, 1882), and the terse statement of Burrill (1884) concerning flower infection by the blight bacteria. Arthur (1885c) wrote: "... toward the end of June... the English hawthorns, which blossom very freely about the middle of May, were seriously affected with blight ... the flowers had long since disappeared and the fruit was well advanced toward maturity. The blighted branches, however, were still crowned with dead flowers. ... The conviction was established that the germs enter the tree in spring through the moist glandular surfaces within the flower or the tender surfaces of expanding buds, but that the disease does not make sufficient progress to become conspicuous till the warm days of June or July. As the flowers drop and the branches cease extending less and less chance exists for the tree to take the disease."

Examination of pear, apple, and quince trees showed a similar phenomenon (Arthur, 1885d). In another work, Arthur (1885c) said: "The query now presents itself whether the germs may not be able to thrive outside the tree. ... it was found that infusions of hay, corn meal, starch and various other vegetable substances make a nutritive fluid in which the blight bacteria flourished in varying degrees. ... When transferred from the culture fluid to the tissues of the tree, the usual form of blight follows." He also used cooked pear fruit, sugar, barnyard manure, and gelatin. "An infusion of almost any vegetable substance containing a fair amount of carbohydrates is likely to be sufficient to enable growth to take place. ..." (Arthur, 1886a).

Because the phenomenon of antagonism between microorganisms was still unknown, Arthur (1885c) fell into the error of concluding from the above that "This plainly indicates that the germs washed from the tree by rain may find congenial nidus among vegetable refuse, thrive and multiply, pass the winter... even pass an unfavorable year or two, and at times being swept into the air be brought by gentle rains or an arresting 
film of dew into contact with the delicate surfaces of expanding shoot or flower and infection be secured." Bacteria from various sorts of rotting plant tissue were inoculated into pear trees without success. From inoculations of these microorganisms mixed with blight bacteria "the resulting blight contained but one sort" of bacteria. The disease was, therefore, due to a specific bacterium.

Arthur presented these studies on fire blight to Cornell University as a doctoral thesis in 1886. This was the first Ph.D. conferred in the field of science by that University. He had previously been a student of C. E. Bessey at Iowa State College. He received honorary degrees from the University of Iowa, Iowa State College, and Purdue University (Kern, 1942a, $b$ ).

\section{Arthur's studies on some supposed bacterial diseases}

Apparently in the flush of enthusiasm from the work on fire blight, Arthur described two other presumed bacterial diseases. Arthur and Golden (1892) described a disease of sugar beet thought to be due to a bacterium. Cunningham (1898), who worked under Arthur, also attributed this disease to bacteria in 1898. However, in 1937 and 1951 this was shown by Coons et al. (1951) to be due to the beet savoy virus.

Arthur and Bolley (1896) described a leaf spot of carnation thought to be due to Bacterium dianthi; this was shown by Woods (1897) to be caused by aphid feeding.

\section{Evaluation of Burrill's and}

\section{Arthur's contributions}

Erwin F. Smith (1885) evaluated the contributions of Burrill and Arthur in 1885: "Professor B [urrill] pushed his experiments far enough to render it very probable that this micrococcus is the cause of the blight. In his own mind there was no doubt whatever, but he cannot be said to have conclusively proved this point. . . . Prof. J. C. Arthur... has finally settled this point ... we may now accept as proved beyond doubt that pear blight is caused by a bacterium ...."

Fourteen years later Smith (1899b) wrote that: "Prof. Burrill, an expert microscopist and mycologist, although working before the era of exact methods in bacteriology, proved four things conclusively; 1 ) The absence of any fungus in the blighting pear twigs; 2) The constant presence of a motile bacillus in enormous numbers in the freshly blighted twigs, which bacillus, moreover, could always be found pushing into the sound tissues some centimeters in advance of the visible browning and death; 3) The infectious nature of the freshly blighted material; 4) The identity of the blight on pear, apple, and quince."

Smith (1916) said in an obituary of Burrill 31 years later: "... in studying the freshly diseased tissues (and he had the wisdom to select just those) he saw clearly in many sections that fungi were not there and that swarms of bacteria... were always present and were therefore probably the cause of this mysterious disease. Acting on this assumption he took masses of these bacteria which his microscope had shown to be free from fungi (with a multitude of whose forms he was already very familiar) and with them by inoculation reproduced the pear disease, not once but many times. . . . Just as Pasteur's contribution to science is more vital than Koch's, because it was earlier and was pioneer work, so Burrill's discovery was more difficult to make and hence more worthy of praise, than anything that has come after."

Smith, a generous and stoutly nationalistic defender of Burrill's contentions, seems to have held a progressively higher opinion of Burrill's contributions with the passage of time. This 
evaluation has been uncritically accepted by textbook writers, and probably has led to their attributing to Burrill proof of the concept that bacteria can cause disease in plants.

It is of interest to examine the above four points listed by Smith (1899b) as established by Burrill. As already indicated, point 3 had been reported four times (Hull, 1871; Ragan, in Gookins, 1846; Turner, 1879; Wendell, 1850) prior to Burrill's studies. Pure-culture methods began to be used (1875-80) in this country by Farlow (Rodgers, 1952) during the time of these studies, but Burrill did not then adopt them in his research. In this connection, however, the description of his 1874 course in Microscopy indicated that he was aware of these methods at that time (Thornberry, 1967). "Such fungi as are known or supposed to be injurious to plants or animals are studied... cultures being made for this purpose,..."

Burrill worked on a disease of broomcorn and sorghum in 1884-86. This was at first reported as due to a fungus (Chaetostroma) but he later obtained "a pure culture" of a bacterium (Bacillus sorghii Burrill), and successfully inoculated with it. M. B. Waite, working under Burrill, found that "The organism was easily obtained in a state of purity by plate cultures...." (Burrill, 1887). It is, therefore, surprising that Burrill's last papers on fire blight still did not use pure-culture methods.

Point 4 had been demonstrated once (Hull, 1871), and point 2 was in part anticipated by Dränert (1869), Woronin (1866), and Davaine (1868) for other bacteria and hosts. Burrill missed the significance of flower infection until this was pointed out to him by a grower. A careful reading of Burrill's papers gives the impression that from 1877 to 1882 he became increasingly convinced of the correctness of his hypothesis, but this confidence seems to have been based more on lack of effective dissent from others - and on pride in a comfortably familiar idea-than on continuing intensive study. The fact that he had demanding University administrative responsibilities (Rodgers, 1952; Thornberry, 1967), and that techniques of the time were crude (Smith, 1899b), is historically immaterial. Even his student and long-term associate, J. T. Barrett (1918) said, "While this result was all but convincing, Burrill fully recognized the incompleteness of his proof. ... To J. C. Arthur . . . it was left to furnish the connecting link of proof as to the bacterial nature of the disease." In a biographical sketch of Burrill, $\mathrm{H}$. H. Thornberry (1967) stated "In 1885, J. C. Arthur published his convincing proof that fire blight was caused by a bacterium."

Arthur's (1886d) summary of Burrill's contributions is worth noting in this regard: "...the disease was due to germs which he found in great quantity in the diseased limbs. He had found that the disease would follow inoculation. This could be done by inserting a little of the juice of a diseased limb into a healthy limb. This was practically the extent of Prof. Burrill's work. It, however, was a very important beginning."

Burrill's erroneous published notions that peach yellows and the toxic principle of poison ivy were bacterial in nature are perhaps germane to this appraisal, as are the subsequent mistakes of Arthur mentioned above. Burrill was an imaginative person of wide interests and considerable persuasiveness and charm (Thornberry, 1967). Several of his studies on other diseases (Burrill, 1889; Doetsch, 1960; Smith, 1914; Thornberry, 1967) were, however, neither thorough nor complete. Is it not probable that he rather tentatively presented the pear-blight, peachyellows, and ivy-toxin ideas on inadequate evidence, and when one was found to accord with the facts, he defended and promoted it by addresses and papers, rather than by continued 
deepening investigations? Burrill's place in history with respect to these studies is perhaps based on the facts that he was proved by others to have been right, and that he had a strong advocate in Erwin F. Smith.

Burrill taught at the Illinois Industrial University (which became the University of Illinois in 1886) probably the first courses in North America which emphasized plant pathology. A course of lectures in 1869 was based on M. J. Berkeley's "Introduction to Cryptogamic Botany." Plant diseases were emphasized in courses in 1872, and by 1874 he gave instruction in plant pathology as part of three courses in the School of Horticulture of the College of Agriculture, and three courses in the School of Natural History of the College of Natural Science. Student microscopes were used in these courses as early as 1877-78. Burrill also offered instruction in bacteriology by 1887 , probably the first nonmedical instruction in this subject in America. In 1898 he taught Botany 7-"Plant Pathology," and Horticulture 101"Studies on Combating Fungous, Insects, and Other Enemies of Plants." Among Burrill's assistants were G. B. Clinton, A. B. Seymour, M. B. Waite, B. M. Duggar, and J. T. Barrett (Thornberry, 1967). Burrill received the honorary Ph.D. from the University of Chicago in 1881, and the LL.D. from Northwestern University in 1893 and from the University of Illinois in 1912. He was president of The American Microscopical Society, the American Society for Microscopy, the Illinois State Horticultural Society (twice), and the Society of American Bacteriologists. The last group passed a congratulatory resolution in 1915, noting that he had "founded the science of bacterial plant pathology,..." (Smith, 1916). It is suggested that Burrill's place in the development of the pro- fession of plant pathology is secure, but should rest more on his pioneer teaching and on administrative activities than on his research.

Smith (1885) credited Arthur with showing that: (1) pear blight was caused by a bacterium, Micrococcus amylovorus Burrill; (2) this bacterium was always present in tissues showing fire blight; (3) this bacterium may be grown for six generations outside of the host on sterilized media without losing its pathogenicity; (4) this bacterium invariably produced blight when introduced, either directly from a diseased tree or after prolonged growth in culture, into the soft parts of healthy trees; (5) if the culture liquid in which the bacterium had grown was carefully filtered to remove the bacteria, the filtrate would not produce the disease, although the residue would.

Smith apparently gave more credit to Arthur than to Burrill in 1885 , but later strongly and effectively supported Burrill's case. The reason for this shift is not known, ${ }^{3}$ but a tantalizing clue is provided by Rodgers (1952): "Smith believed that not only was Arthur's technique better than Burrill's but also that Burrill's student, M. B. Waite, finally isolated and worked out the cultural characters of the 'right' causal organism (letter, Smith to L. R. Jones, February 24, 1914). Arthur (letter, Arthur to Smith, December 30, 1899) in 1899 found Smith's evaluation of his work was an 'excellent and discriminating statement....I have known for some time that I had confounded in my published accounts a non-pathogenic with the true pear blight bacillus, but that chiefly affected the morphological part of my work.' "

In this connection, F. D. Kern (1942a, $b$ ), a student of Arthur, failed to mention in his obituaries of Arthur the important proof that bacteria could produce plant disease, as also did

${ }^{3}$ M. W. Gardner and F. D. Kern have indicated that they knew of no estrangement between Arthur and Smith that might account for this. 
Edington (1942). Could Arthur's subsequent high reputation as a uredinologist have so overshadowed his earlier work that plant pathologists, even Smith and Kern, tended to forget or to underrate his studies on fire blight?

Riker and Hildebrandt (1954) overlooked Arthur's work completely, stating that "Burrill soon proved the disease... was caused by bacteria," and crediting Smith and his associates with carrying the work forward. In fact, the U. S. Department of Agriculture Yearbook of 1953, in which this article appears, mentions Arthur only once, and then in connection with rusts. Mayer (1959) also ignores Arthur's studies on fire blight. Stevenson (1959), in a discussion of the history of plant pathology in the United States, merely noted that Arthur "through inoculation experiments definitely confirmed Burrill's results" and Burrill demonstrated "bacteria as the cause of fire blight of pome fruits." Whetzel (1918), Heald (1933), Large (1940), Rodgers (1952), Keitt (1959), Orlob (1964), and Walker (1969), among others, gave essentially the same interpretation. The biographies of Arthur in Who's Who in America and American Men of Science, for which he must have submitted data and which he had opportunity to edit, also failed to mention his fire-blight work.

On the question of the final proof of the causal nature of the bacteria in plant disease, the fulfillment of Koch's Postulates may afford a useful criterion (see also table on page 624):

(1) Constant association of bacteria with the disease, and lack of such association with other microorganisms. This was established for fire blight by Burrill $(1879,1882 a)$ and confirmed by Arthur (1885b). The earlier work of Dränert (1869) and Davaine (1868) was not convincing, and that of Woronin (1886) was not concerned with a plant disease.

(2) Isolation of the causal organism in pure culture. This was not attempted for fire blight by Burrill, but the pathogen was isolated and carried through six serial transfers by Arthur (1885a) in sterile media; since the final transfers were still virulent, it is probable that the cultures were pure (Smith, 1899b). Wakker's first pure cultures were obtained in 1886 (Wakker, 1884-87).

(3) Inoculation of the host with the pure culture produces the original disease. Burrill (1881b) successfully inoculated with infected tissue and with exudate (but four others had done this earlier), Arthur (1885a) with pure cultures in 1884, Wakker (1884-87) with pure cultures in 1886, and Savastano (1887) in 1887. Arthur (1885a) also showed by filtration that the bacteria, rather than the sap from diseased plants, caused the disease.

(4) Reisolation of the original pathogen from the diseased host. Burrill (1879) and Arthur (1885b) showed that bacteria were abundant in the inoculated host, but there is no positive evidence that either recovered them from inoculated plants. The only suggestion of it is provided by Arthur (1886a): "If blight bacteria in active condition are intermixed with the other forms, they ... bring about... the disease, but the associated forms disappear the same as when introduced alone, and the product is a mass of practically pure blight bacteria." How could this have been determined except by reisolation? It would appear (Smith, 1911) that Waite (1891) first definitely cultured the bacteria from inoculations made on flowers.

On the basis of this analysis, it seems clear that Arthur, rather than Burrill, first presented convincing proof that bacteria could cause plant disease, and that this was in 1884-85. However, there were many growers and investigators from 1846 to 1901 who made vital contributions to the elucidation and acceptance of the concept.

The statements of T. Meehan, editor 


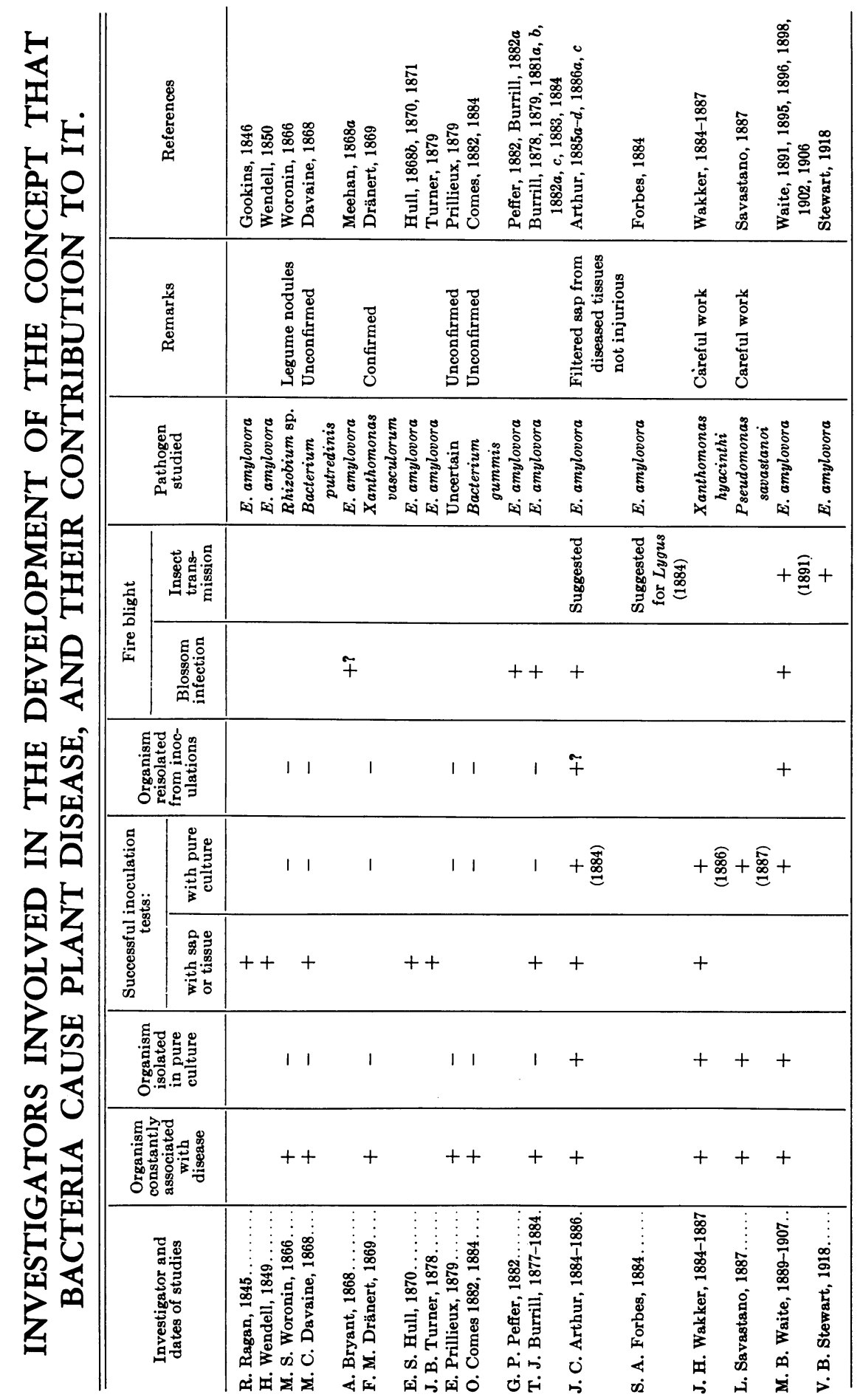


of The Gardeners' Monthly, portray the impact of the work of these men on horticultural thinking. $\mathrm{He}$ (1885) complained: "The idea that fire blight is contagious or even infectious, is surely thoroughly exploded.... We really believe that a number of our good friends among the professors of horticulture ... are a long way behind the age, and a good course of reading through the horticultural publications of the past twenty-five years, before putting their fancied discoveries into print, would be of great service to them." The following year, however, Meehan (1886) wrote: "It is long since the Gardeners' Monthly took the stand that fire blight must of necessity be of fungus origin .... some parasitic action must be the acting power in inducing fire blight. . . . Professor Burrill's proposition that the disease was caused by the presence of Bacteria, was fully in accord with our prepossessions."

\section{THE PERIOD AFTER 1886}

Forbes (1884) observed fire blight in association with the feeding of the insect, Lygus pratensis, and thought it to be a vector. This was confirmed by Stewart (1913) nearly 30 years later.

It is remarkable that the logical inference from the idea of Peffer (Burrill, 1882a; Peffer, 1882), confirmed by Burrill (1884) and by Arthur (1885c, $d, 1886 c)$, that flowers were a highly vulnerable point of infection was so long in coming.

\section{B. Waite and the demonstration of insect transmission of plant disease}

M. B. Waite began work on the disease in 1889, and in two short abstracts (Waite, 1891) reported that the blight bacterium multiplied saprophytically in the nectar of the pear floral nectaries, which were killed. It was carried from flower to flower by bees and other insects visiting them for pollen and nectar. An artificial epidemic was started by infecting the flowers of a few trees on the edge of an orchard, and allowing free access of insects. Conversely, mosquito-net bags over the flowers kept out the insects in a Maryland test, and protected the flowers from blight. This was the first experimental demonstration of insect transmission of a plant pathogen, either microorganism or virus.
Waite $(1895,1896,1898)$ summarized his general observations and presented some new data: "Climatic conditions greatly influence the disease, warm and moist weather, with frequent showers, favoring it; dry, cool, and sunny weather hindering it, and very dry weather soon checking it entirely. The pear-blight microbe.... In the blighted twigs exposed to ordinary weather...dries out in a week or two and dies. ... It has been claimed that the blight microbe lives over winter in the soil, . . . but ... in no instance could it be found there. Unless the microbes keep on multiplying and extending in the tree, they soon die out. ... In certain cases ... when the tree goes into a dormant condition, active blight is still at work in it.... the blight usually continues through the winter. ... When root pressure begins in early spring ... the microbes which have lived over winter ... . extend into new bark. ... The warm and moist weather which usually brings out the blossoms is particularly favorable to the ... disease ... and the gum is exuded copiously from ... the bark. ... Bees, wasps, and flies are attracted to this gum, and undoubtedly carry the microbes to the blossoms. From these first flowers it is carried to others. ... The key to the whole situation is found in those cases of active blight (comparatively few) 
which hold over winter. If they can be found and destroyed, the pear-blight question will be solved. . . . It is important to cut out blight whenever it is found, even in the growing season. ... However, when the trees stop forming new wood, the campaign should begin in earnest." (Waite, 1896.)

A good account of these studies was also given by Smith (1911): "In 1891, Waite sprayed pure cultures of Bacillus amylovorus upon pear-flowers and obtained many cases of blossom-blight. ... Bees were observed to visit the infected flowers and, subsequently, flowers on other clusters, which flowers afterwards blighted. Some of these bees were caught, their mouth parts excised, and cultures made therefrom. . . . Colonies obtained ... closely resembled the pearblight organism, and inoculations therefrom produced the disease in sound pear-shoots, thus demonstrating beyond dispute the actual presence of the pearblight organism on the mouth parts of the suspected bees."

Insects and birds were also thought to be agents of dispersal and infection of new shoots.

The specific name of the bacterium was found to have been poorly chosen because the pathogen does not digest starch (Waite, 1898).

Waite (1902) stated that: "...by far the greater number of infections are directly through the blossom. ... Ordinarily, trees do not have the blight very badly until they come into bloom. ... The germs of the pear-blight are found growing and multiplying in this nectar. . . . We inoculated about 6 or 8 trees, and about eight or ten small branches on each tree. Before inoculating them, I covered a large portion of the tree with bags of various density. ... The disease gradually spread from my centers of infection, but in no case did the disease get through the mosquito-netting, although a large percentage of the clusters broke down on the trees that were infected, outside of the mosquito-netting. We inoculated blight in the bags and kept it in; we inoculated it outside, and kept it out ..."

Waite (1906) pointed out, in an excellent general discussion, that: "The gum exudate pushes out of the infected blossoms, ... and honey-bees, wild bees, wasps, flies, and a great variety of insects visit the pear blossoms . .., carrying the infected material. . . Occasionally a humming-bird visits the infected blossoms. . . . Doubtless birds, getting the gummy material stuck to their feet, carry the blight long distances. ... Sapsuckers become infected by puncturing cases of hold-over blight, and start the disease in healthy trees. . . . We look upon insect distribution as by far the most important means of infection, especially on blossoms. . . . Young orchards are not usually attacked by the blight, rather rarely in fact, until they have blossomed.... it is possible to infect the blight in the cut surface and even to carry it on the pruning tools. ... As a rule, spraying is of little use.... In the blossoming season new blossoms are opening every hour of the day...."

The infection experiments of Arthur and Waite were independently confirmed by Chester (1901, 1903). The idea of these investigators that infection was largely from blossom invasion was questioned by Gossard and Walton (1917), who observed as early as 1913 that the bacteria may also be spread in water or wind-blown mist, and that infection also readily occurred in unwounded young leaves and twigs.

The demonstration of transmission of a plant pathogen by an insect (Waite, 1891) and an animal pathogen by another arthropod, a tick (Smith and Kilborne, 1893), were contemporaneous. Theobald Smith and F. L. Kilborne investigated the Texas cattle fever (caused by a protozoan) from 1889 to 1893 , and showed in 1891 that it was carried by a tick and was passed 
to the young through the egg (Smith and Kilborne, 1893). Earlier studies by $\mathrm{P}$. Manson in 1878-1884 on transmission by mosquitoes of the nematode which causes elephantiasis were not conclusive, but this was proved by G. C. Low in 1900 . Other studies later than Smith and Kilborne were by: $R$. Ross in 1898, showing transmission of protozoa of bird malaria by mosquitoes; D. Bruce in 1895, showing transmission of the trypanasomes of nagana disease of cattle by tsetse flies; W. Reed in 1900 demonstrating transmission of the virus of yellow fever by mosquitoes.

\section{The Smith-Fischer controversy}

Writers of bacteriology text and reference books only slowly accepted the idea that bacteria caused important diseases of plants, as was discussed by Smith $(1896 a, 1911)$. Prominent bacteriologists and botanists, such as $R$.
Hartig, A. de Bary, H. M. Ward, W. Migula, A. B. Frank, P. Sorauer, K. F. von Tubeuf, W. G. Smith, O. Kirchner, and $\mathrm{C}$. Wehmer continued to express scepticism or cautious uncertainty about their importance until the end of the century. Alfred Fischer (1897) expressed this prevalent sentiment in his textbook, "Vorlesungen über Bakterien," somewhat more emphatically than had his contemporaries. Erwin F. Smith (1899a) disputed this in an equally forceful and sarcastic paper. Fischer may well have been surprised at this reaction to a commonplace viewpoint; in any case he stubbornly and vigorously defended his erroneous view (Fischer, 1899). Smith (1899b, 1901) replied, and thus ended the bitter Smith-Fischer controversy of 18991901. After this, the fact that bacteria were important plant pathogens was generally accepted.

\section{CONCLUSIONS}

An analysis of the pertinent literature of the time has shown that many growers and investigators were involved from 1846 to 1901 in the development and final acceptance of the concept that bacteria were able to cause disease of plants as well as of animals. If any one person must be singled out as having proved this point it would have to be J. C. Arthur in 1884-85, rather than Thomas J. Burrill in 1877-83 as commonly stated. That bacteria were able to do this was generally accepted, however, only after the 1899-1901 polemic between Erwin F. Smith and Alfred Fischer on this point. As usual, it was perceptive growers who made many of the original observations and deductions which led investigators to the essential facts of the cause of fire blight disease.
Burrill's place in the history of plant pathology is secure on the basis of his pioneer teaching of the subject and on his administrative activities.

Insect transmission of a plant pathogen, either microorganism or virus, was first demonstrated by M. B. Waite in 1891 with the fire-blight bacterium about the same time that other arthropods (ticks) were shown to spread an animal disease, the protozoan of Texas cattle fever.

Establishment of the critical details necessary to effectively control this important and highly epidemic disease thus led to the development of two concepts important to plant pathology and agriculture:

- Bacteria are able to cause serious diseases of plants.

- Insects provide an efficient means of dissemination of plant pathogens. 


\section{ACKNOWLEDGMENTS}

M. W. Gardner and F. D. Kern kindly read the manuscript and made numerous helpful suggestions concerning it, based on their personal acquaintance with Arthur, Burrill, and Smith. F. H. Bollman advised on data concerning pear production. The manuscript was reviewed by B. Kennedy, M. F. Schroth, and J. H. Shideler. W. H. Fuller prepared the figures. The original documents cited were consulted in the libraries of Pennsylvania State University, Cornell University, and the University of California, Berkeley.

\section{LITERATURE CITED}

\section{ANONYMOUS}

1829. Blight in pear trees, etc. New Engl. Farmer 8:57.

1863. Pear blight. Trans. Ill. State Hort. Soc. 1861-62:124-27.

1902. Review of the fruit seasons. Calif. State Bd. Hort. Bienn. Rept. 8:21-50.

1905. Review of the fruit seasons. Calif. Comm. Hort. Bienn. Rept. 1:53-75.

1907. Review of the fruit season. Calif. Comm. Hort. Bienn. Rept. 2:28-34.

1924. Pear. Fire blight caused by Bacillus amylovorus (Burrill) Trev. Plant Dis. Reptr. Suppl. 33:89-90.

Arthur, J. C.

1885a. Proof that bacteria are the direct cause of the disease in trees known as pear blight. Bot. Gaz. 10:345-45. [Also in Proc. Amer. Assoc. Advanc. Sci. 34:295-98. 1885; Gard. Chron. 24:586. 1885.]

1885b. Report of the Botanist. Diseases of the pear. Pear blight. N. Y. (Geneva) Agr. Exp. Sta. Ann. Rept. 3:357-67.

1885c. Pear blight and its cause. Amer. Naturalist 19:1177-85.

1885d. Proof that the disease of trees known as pear blight is directly due to bacteria. N. Y. (Geneva) Agr. Exp. Sta. Bul. 2 n.s.:1-4.

1886a. History and biology of pear blight. Proc. Acad. Nat. Sci., Philadelphia 38:322-41.

$1886 b$. Pear blight, its cause and prevention. Proc. N. J. State Hort. Soc. 9:133-47.

1886c. Report of the Botanist. Pear blight. N. Y. (Geneva) Agr. Exp. Sta. Ann. Rept. 4: 268-75.

1886d. Pear blight. Proc. Amer. Pomol. Soc. 20:44-47.

ARThur, J. C., and H. L. Bolley

1896. Bacteriosis of carnations. Indiana Agr. Exp. Sta. Bul. 59:15-29.

ArThur, J. C., and K. E. Golden

1892. Diseases of the sugar beet root. Indiana Agr. Exp. Sta. Bul. 39:54-62.

BAKER, C. R.

1866. Practical and scientific fruit culture. Pp. 476-79. Boston: Lee and Shepard, 523 pp.

BARRETT, J. T.

1918. Thomas Jonathan Burrill (1839-1916). Phytopathology 8:1-4.

BARRY, P.

1847. Pear tree blight. Horticultural Department. Genesee Farmer 7:122-23, 218-19.

BEECHER, H. W.

1844. The blight in the pear tree; its cause and a remedy for it. Mag. Hort. 10:441-56.

BeIJERINCK, M. W.

1888. Die Bacterien der Papilionaceenknöllchen. Bot. Zeit. 46:726-35, 758-71, 782-90, 798803.

Bitancourt, A. A.

1943. Plant pathology in Brazil. Chron. Bot. 7:318-20.

Borecki, Z., W. Basak, B. ZaWAdska, and D. F. Millikan

1967. Fire blight in continental Europe. Plant Dis. Reptr. 51:3.

Buell, J.

1827. The disease in pear and apple trees. New Engl. Farmer 6:108.

1828. Fire blight. On the insects that injure the apple tree. New Engl. Farmer 7:137, 169.

BuLLOCH, W.

1938. The history of bacteriology. p. 230. New York: Oxford University Press. 422 pp.

Burrill, T. J.

1877. Horticulture Department Report, September 13, 1876, to Dr. J. M. Gregory, Regent. Rept. Bd. Trustees Ill. Indust. Univ. 8:199-200.

1878. Report on botany and vegetable physiology. Trans. Ill. State Hort. Soc. 11:114-16. 
1879. In Discussion on the Reports. Trans. Ill. State Hort. Soc. 12:79-80.

1881a. Blight of pear and apple trees. Rept. Bd. Trustees Ill. Indust. Univ. 10:62-84.

$1881 b$. Anthrax of fruit trees; or the so-called fire blight of pear, and twig blight of apple trees. Proc. Amer. Assoc. Advanc. Sci. 29:583-97. [Also in Trans. Ill. State Hort. Soc. $14: 157-67.1880$.

1881c. Bacteria as a cause of disease in plants. Amer. Naturalist 15:527-31.

1882a. Bacteria and their effects. Trans. Ill. State Hort. Soc. 15:165-84.

1882b. Have we any new light on pear blight or yellows? Mich. State Hort. Soc. Ann. Rept. 1881:133-39.

1882c. The bacteria: an account of their nature and effects, together with a systematic description of the species. Rept. Bd. Trustees Ill. Indust. Univ. 11:93-157.

1882d. Some vegetable poisons. Amer. Monthly Microscop. Jour. 3:192-97. [Also in Proc. Amer. Assoc. Advanc. Sci. 31:515-18. 1883.]

1883. Botany. New species of Micrococcus (Bacteria). Amer. Naturalist 17:319.

1884. Pear blight and peach yellows. Trans. Ill. State Hort. Soc. 17:46-49.

1885. Trunks of apple trees. Trans. Wisc. State Hort. Soc. 15:215-29.

1887. Disease germs. Another illustration of the fact that bacteria cause disease. Proc. Amer. Soc. Microscopists 9:193-206. [Also in Microscope (Detroit) 7:321-31. 1887; Proc. Soc. Prom. Agr. Sci. 1887:30-36. 1887.]

1889. A bacterial disease of corn. Ill. Agr. Exp. Sta. Bul. 6:165-75.

Burrill, T. J., and R. HANSEN

1917. Is symbiosis possible between legume bacteria and non-legume plants? Ill. Agr. Exp. Sta. Bul. 202:112-81.

Chauncey, C. W.

1905. Reports of the County Boards of Horticulture. Fresno County. Calif. Comm. Hort. Bienn. Rept. 1:156-57.

Chester, F. D.

1901. Pear blight and pear canker. Delaware Agr. Exp. Sta. Bul. 52:1-8.

1903. Pear blight notes. Delaware Agr. Exp. Sta. Ann. Rept. 14:41-43.

Chisholm, L. C.

1905. Zymotic pear blight. Calif. Comm. Hort. Bienn. Rept. 1:125-35.

CifERri, R.

1955. Preliminary list of noteworthy diseases of cultivated plants in continental eastern China. Plant Dis. Reptr. 39:785-92.

Cockayne, A. H.

1920. Fire blight. A serious disease of fruit-trees. New Zealand Jour. Agr. 20:156-57.

Comes, O.

1882. Sul preteso tannino solido scoperto nelle vite affete dal Mal nero. L'Agricultura Meridionale 5:202.

1884. Il marciume della radici e la gommosi della vite. Naples. p. 14.

Commonwealth Mycological Institute

1969. Distribution maps of plant diseases No. 2, Ed. 5. Kew, England.

Cooke, S. S.

1867. Pear blight. Gard. Monthly 9:73-78.

Coons, G. H., J. E. Kotila, and D. StewarT

1951. Savoy, a virus disease of beet transmitted by Piesma cinerea. Proc. Amer. Soc. Sugar Beet Technol. 6:500-01. [Also in Phytopathology 27:125. 1937.]

Coxe, W.

1817. A view of the cultivation of fruit trees, and the management of orchards and cider. Pears. Pp. 174-76. Philadelphia: M. Carey and Son. 268 pp.

Crosse, J .E., M. Bennett, and C. M. E. Garrett

1958. Fire-blight of pear in England. Nature 182:1530.

Cunningham, C. A.

1898. A bacterial disease of the sugar beet. Proc. Soc. Prom. Agr. Sci. 15:141-43.

Cutter, G. H.

1907. Reports of the County Boards of Horticulture. Sacramento County. Calif. Comm. Hort. Bienn. Rept. 2:295-97.

Davaine, M. C.

1868. Bactérie. 5. Bacterium de la pourriture. Dictionaire Encyclopédique des Sciences Médi-

DenNing, W. cales 8:25. Paris: V. Masson.

1794. On the decay of apple trees. Trans. Soc. Prom. Agr., Arts, Mfg. 2:219-22. (2nd ed., 2:185-87. 1801.) 
DoETsCH, R. N.

1960. Microbiology. Pp. 108-15. New Brunswick, N.J.: Rutgers Univ. Press. 233 pp.

Downing, A. J.

1845. Fruits and fruit-trees of America. New York: John Wiley. 594 pp.

DRÄNERT, F. M.

1869. Bericht über die Krankheit des Zuckerrohres. Weitere Notizen über die Krankheit des Zuckerrohres. Zeitschr. Parasitenkunde 1:13-17, 212.

Eastham, J. W.

1924. Fire-blight (Bacillus amylovorous). Brit. Col. Dept. Agr. Circ. 66 (New Hort. Ser.) : $1-8$.

EAton, L. C.

1847. A review of opinions of pear tree blight. Horticulturist 1:459-63, 495-500.

Edington, W. E.

1942. Joseph Charles Arthur. Proc. Ind. Acad. Sci. 52:1-3.

El-Helaly, A. F., M. K. Ab-El-Dahab, and M. A. El-Goorani

1964. The occurrence of the fire blight disease of pear in Egypt. Phytopath. Medit. 3:156-63.

ELLIOTT, C.

1930, 1951. Manual of bacterial plant pathogens. Baltimore, Md.: Williams and Wilkins Co., 349 pp. (2nd. ed., Waltham, Mass. : Chronica Botanica Co., 186 pp. 1951.)

ERNST, A. H.

1848. On the fire blight in pear trees. Horticulturist 2:328-31.

Fischer, A.

1897. Vorlesungen über Bakterien. Pp. 131-32. Jena: G. Fischer. 186 pp.

1899. Die Bakterienkrankheit der Pflanzen. Centralbl. Bakt., II, 5:279-87.

Fletcher, S. W.

1931-1933. A history of fruit growing in Pennsylvania. Proc. Penn. State Hort. Assoc. 72: $1-26 ; 73: 27-52 ; 74: 53-76$.

Forbes, S. A.

1884. The tarnished plant bug. Farmers' Review Feb. 28, 1884, p. 150.

Fowler, P., S. A. BAgGS, and C. S. RILEY

1902. Reports of the County Boards of Horticultural Commissioners. Tulare County. Calif. State Bd. Hort. Bienn. Rept. 8:237-38.

Gardner, M. W., and P. A. ARK

1964. Early references to pear blight in California. Plant Dis. Reptr. 48:871-72.

G[ookIns], S. B.

1846. Remarks on the pear blight of the west. Horticulturist 1:253-56.

Gossard, H. A., and R. C. WALTON

1917. Rain proves an important carrier of disease in open orchards. Ohio Agr. Exp. Sta. Mo. Bul. 2:357-64.

Grainger, I. L., C. M. Glazier, and R. F. JACK

1901. Reports of the County Boards of Horticultural Commissioners. Fresno County. Calif. State Bd. Hort. Bienn. Rept. 7:214-16.

HaLlam, J. L.

1883. Report on general horticulture for the Fifth District. Trans. Ill. State Hort. Soe. 16: 116-20.

HARRISON, F. C., and B. BARLOW

1904. Some bacterial diseases of plants prevalent in Ontario. Ontario Agr. Coll. Bul. 136: $1-20$.

HEALD, F. D.

1933. Manual of plant diseases. First ed. New York: McGraw-Hill Book Co., 891 pp.

HEDRICK, U. P.

1917. The peaches of New York. New York Dept. Agr. Ann. Rept. 24, 2 (part 2), 541 pp.

1921. The pears of New York. New York Dept. Agr. Ann. Rept. 29, 2 (part 2), 636 pp.

1933. A history of agriculture in the State of New York. Albany, N.Y.: J. B. Lyon Co., 462 pp.

HooK, $\mathrm{S}$.

1943. The hero in history. New York: Humanities Press, 273 pp.

HULL, E. S.

1869. Cryptogamous diseases. Root-pruning the pear-a preventive of blight. Root rot. Trans. Ill. State Hort. Soc. 2:35-39, 57.

1870. Report of State Horticulturist. Pear, apple and quince tree blight. Trans. Ill. State Hort. Soc. 3:97-103.

1871. Twig blight of the apple. Trans. Ill. State Hort. Soc. 4:220-23. 
JAMES, J. H.

1849. The blight in pear trees. Mag. Hort. 15:13-23.

Johansen, A. F.

1969. Afprøvning af forskellige fungiciders virkning på Ildsot (Erwinia amylovora) in vitro. Tidsskrift Planteavl 73:461-63.

KeITT, G. W.

1959. History of plant pathology. In J. G. Horsfall and A. E. Dimond (ed.), Plant Pathology, an advanced treatise 1:62-97. New York: Academic Press, 674 pp.

KenNicotT, J. A.

1851. Random thoughts and observations on pomology, and kindred subjects, in Illinois and the west. Ohio Bd. Agr. Ann. Rept. 5:568-600. [Also in Proc. Amer. Pomol. Soc. 1:3769. 1851.]

KERN, F. D.

1942a. Joseph Charles Arthur. Science 95:617-19.

1942b. Joseph Charles Arthur. Phytopathology 32:833-44.

KLARUP, J.

1969. Fire blight'en pa Nordfalster. Erhversfrugt 36:143-46.

KLeE, W. G.

1889. Is it the eastern fire blight 9 Pacific Rural Press 37:113.

KосH, R.

1876. Die Aetiologie der Milzbrand-Krankheit, begründet auf die Entwicklungsgeschichte des Bacillus anthracis. In F. Cohn, Beiträge zur Biologie der Pfianzen 2(2):277-310. Breslau.

LARGE, E. C.

1940. The advance of the fungi. New York: Henry Holt and Co., $488 \mathrm{pp.}$

LOWELL, J.

1826. Disease in pear trees. Insect in pear trees. On the old and familiar disease of the pear tree in summer. New Engl. Farmer 5:1-2, 17-18, 42.

Maas Geesteranus, H. P.

1966. Bacterieziekten bij planten, algemeen. Ontwikkeling van methoden voor bacteriediagnostiek. Inst. Plantenziektenkundig Onderzoek Jaarverslag (Wageningen) 1966:46-47.

Massachusetts Records

1853. Massachusetts Records 1:24. Boston: William White.

MAYER, K.

1959. 4500 Jahre Pflanzenschutz. Stuttgart: Eugen Ulmer, 45 pp.

MeEhaN, T.

1868a. Diseases of the pear. Trans. Ill. State Hort. Soc. 1:48-59.

1868b. Diseases of the pear. Proc. Amer. Pomol. Soc. 11:57-69.

1885. Fire blight in the pear. Gard. Monthly 27:207-08.

1886. Fire blight in the pear. Gard. Monthly 28:25-26.

MeEhan, T., and J. G. HunT

1875. Pear blight. Gard. Monthly 17:245.

MORRISON, A. E.

1931. Sacramento County. Fruit tree removals and plantings for 1930. Calif. Dept. Agr. Mo. Bul. 20:350-52.

MY, H.-T.

1965. [I. Observations on the plant diseases and their control in South Viêt-Nam. II. A preliminary list of plant diseases in South Viêt-Nam.] Saigon: Directorate of Research, 142 pp. [Abst. in Rev. Appl. Mycol. 46:3031.]

ORLOB, G. B.

1964. The concepts of etiology in the history of plant pathology. Pflanzenschutz-Nachrichten Bayer 17:185-264.

Peffer, G. P.

1881. Rust or mildew, its effect on fruit and grain. Trans. Wisc. State Hort. Soc. 11: 228-32.

1882. Apple tree blossoms-blight. Trans. Wisc. State Hort. Soc. 12:191-98.

Prillieux, E.

1879. Sur la coloration et le modes d'alteration de grains de blé roses. Ann. Sci. Nat., Bot. 8: 248-58.

Puttemans, A.

1940. [Some data concerning the history of phytopathology in Brazil and the first notices of diseased plants in the country. Transl. by A. E. Jenkins and A. D'Armand Marchant.] Jour. Agr. Univ. Puerto Rico 24:77-107. 
RAMIREZ, R.

1921. Plagas de la Agricultura en el Distrito Federal. La Revista Agricola (Mexico) 5:66263.

Riker, A. J., and A. C. Hildebrandt

1954. Bacteria—small and mighty. U. S. Dept. Agr. Yrbk. 1953:10-15.

RILEY, C. S.

1905. Reports of the County Boards of Horticulture. Tulare County. Calif. Comm. Hort. Bienn. Rept. 1:184.

RoBles Gutíkrez, L. H.

1943. Principales plagas del manzano en la región de Canatlán, Dgo. Fitofilo 2(6) :3-30.

RODGERS, A. D. III

1952. Erwin Frink Smith. A story of North American plant pathology. Pp. 99-119. Philadelphia: American Philosophical Society, 675 pp.

Salisbury, J. H., and C. B. Salisbury

1864. Microscopic researches: Resulting in the discovery of what appears to be the cause of the so-called blight in apple, pear and quince trees, and the decay of their fruit, etc. Ohio State Bd. Agr. Ann. Rept. 18:450-60, 469, 473-76.

Savastano, L.

1887. La tubercolosi dell'olivo. Ann. R. Scuola Super. d'Agr. in Portici 5 (fasc. 4).

SCHELL, F. C.

1907. Reports of the County Boards of Horticulture. Fresno County. Calif. Comm. Hort. Bienn. Rept. 2:279.

Schieber, E., and J. SANCHEZ

1968. Lista preliminar de las enfermedades de las plantas en Guatemala. Min. Agr. Dir. Gen. Invest. y Ext. Agr., Guatemala. (Cited by van der Zwet, 1968a.)

Sмiтh, E. F.

1885. Recent literature concerning pear blight. Mich. (Amer.) Horticulturist 1(2):34-36.

$1896 a$. The bacterial diseases of plants: A critical review of the present state of our knowledge. I. Amer. Naturalist 30:626-43.

1896b. The bacterial diseases of plants: A critical review of the present state of our knowledge. II. The hyacinth (Hyacinthus orientalis L.). 1. The yellows disease (1883). Amer. Naturalist 30:797-804, 912-24.

1899a. Are there bacterial diseases of plants? Centralbl. Bakt., II, 5:271-78.

$1899 b$. Dr. Alfred Fischer in the rôle of pathologist. Centralbl. Bakt. II, 5:811-17.

1901. Entgegnung auf Alfred Fischer's "Antwort" in betreff der Existenz von durch Bakterien verursachten Pflanzenkrankheiten. Centralbl. Bakt., II, 7:88-100, 128-39, 190-99.

1911. Bacteria in relation to plant diseases. 2:7-22, 54-55. Washington, D.C.: Carnegie Inst., $309 \mathrm{pp}$.

1914. Bacteria in relation to plant diseases. 3:3-5, 147. Washington, D.C.: Carnegie Inst., $368 \mathrm{pp}$.

1916. In memorium, Thomas J. Burrill. Jour. Bact. 1:269-71.

1920. An introduction to bacterial diseases of plants. Pp. 359-88. Philadelphia: W. B. Saunders Co. 688 pp.

Smith, T., and F. L. Kilborne

1893. Investigations into the nature, causation, and prevention of Texas or southern cattle fever. U. S. Dept. Agr. Bur. Animal Ind. Bul. 1:1-301.

Stevenson, J. A.

1959. The beginnings of plant pathology in North America. In C. S. Holton et al., Plant pathology, problems and progress 1908-1958. Pp. 14-23. Madison: Univ. Wisconsin Press. 588 pp.

Stewart, V. B.

1913. The importance of the tarnished plant bug in the dissemination of fire blight in nursery stock. Phytopathology 3:273-76.

SWingle, D. B.

1921. Pear and apple blight in Montana. Mont. Agr. Exp. Sta. Cire. 98:1-10.

TAYLOR, T.

1877. Microscopic investigation. Rept. U. S. Commiss. Agr. 1876:74-81.

TAYLOR, W. A.

1898. The fruit industry, and substitution of domestic for foreign-grown fruits. U. S. Dept. Agr. Yrbk. 1897:305-44. 
THORNBERRY, H. H.

1967. Thomas Jonathan Burrill's contribution to the history of microbiology and plant pathology. Trans. Ill. State Hort. Soc. 100:19-42.

TICE, J. H.

1879. In Discussion on the Reports. Trans. Ill. State Hort. Soc. 12:77-78.

TuRNER, J. B.

1879. In Discussion on the Reports. Trans. Ill. State Hort. Soc. 12:80-81.

UYEDA, E.

1903. On the causal bacteria of fire blight of apple. Dai-Nippon Nokaiho 260: 1-3. (In Japanese.) (Cited by van der Zwet, 1968.)

VAN DER ZWET, T.

1968a. Recent spread and present distribution of fire blight in the world. Plant Dis. Reptr. 52: 698-702.

1968b. Review of fire blight control measures in the United States. Trans. Ill. State Hort. Soc. 101:63-71.

1970. New outbreaks and current distribution of fire blight of pear and apple in northern Europe. FAO Plant Prot. Bul. 18:83-88.

WAITE, M. B.

1891. Results from recent investigations in pear blight. Bot. Gaz. 16:259. [Also in Proc. Amer. Assoc. Advanc. Sci. 40:315. 1892.]

1895. The remedy for pear blight. Science 1 n.s.:721.

1896. The cause and prevention of pear blight. U. S. Dept. Agr. Yrbk. 1895:295-300.

1898. The life-history and characteristics of the pear-blight germ. Proc. Amer. Assoc. Advanc. Sci. 47:427-28.

1902. The relation of bees to the orchard. Natl. Beekeepers' Assoc. Ann. Rept. 32:70-73. [Also in Calif. Cultivator 18:390-91. 1902.]

1906. Pear-blight work and its control in California. Off. Rept. Fruit-Growers' Conv. Calif. 31:137-55.

WAKKER, J. H.

1884. Vorläufige Mitteilungen über Hyacinthenkrankheiten. Bot. Centralbl. 14:315-17.

1884-87. Het geel- of nieuwziek der Hyacinthen veroorzaakt door Bacterium Hyacinthi Wakker. Verslag over het jaar 1883:4-13. 1884; 1884:1-11. 1885; 1885:1-5, 27-37. 1887. Haarlem.

WALKER, J. C.

1969. Plant pathology. 3rd ed. New York: McGraw-Hill Book Co., 819 pp.

WEAVER, W. D.

1902. Reports of the County Boards of Horticultural Commissioners. Fresno County. Calif. State Bd. Hort. Bienn. Rept. 8:217-18.

WeNDELL, H.

1850. Report of Dr. Herman Wendell, of Albany. Pears. U. S. Patent Off. Rept. 1849 (part 2) : 446-48.

WHETZEL, H. H.

1918. An outline of the history of phytopathology. Philadelphia: W. B. Saunders Co., $130 \mathrm{pp}$. Wilson, J.

1907. Investigations by the pathologists. U. S. Dept. Agr. Yrbk. 1906:41.

Woods, A. F.

1897. Bacteriosis of carnations. Bot. Gaz. 24:200-05.

Woronin, M. S.

1866. Ueber die bei der Schwarzerle (Alnus glutinosa) und bei der gewöhnlichen Gartenlupine (Lupinus mutabilis) auftretenden Wurzelanschwellungen. Mém. Acad. Imp. Sci. St. Petersburg, Sér. VII, 10(6):1-13. 


The journal HILGARDIA is published at irregular intervals, in volumes of aloout 650 to 700 pages. The number of issues per volume varies.

Single copies of any issue may be obtained free, as long as the supply lasts; please request by volume and issue number from:

\section{Agricultural Publications \\ University of California \\ Berkeley, California $\mathbf{9 4 7 2 0}$}

The limit to nonresidents of California is 10 separate titles. The limit to California residents is 20 separate titles.

The journal will be sent regularly to libraries, schools, or institutions in one of the following ways:

1. In exchange for similar published material on research.

2. As a gift to qualified repository libraries only.

3. On a subscription basis $-\$ 7.50$ a year paid in advance. All subscrip ions will be started with the first number issued during a calendar year. Subscribers starting during any given year will be sent back numbers to the first of that year and will be billed for the ensuing year the following January. Make checks or money orders payable to The Regents of The University of California; send payment with order to Agricultural Publications at above address. 